\title{
Özel Sermayeli Bankaların Kurumsal Sürdürülebilirlik Performanslarının Değerlendirilmesine Yönelik Çok Kriterli Bir Yaklaşım: Entropi-ARAS Bütünleşik Modeli ${ }^{1}$
}

Fatih Ecer ${ }^{2}$

\begin{abstract}
Özel Sermayeli Bankaların Kurumsal Sürdürülebilirlik Performanslarının Değerlendirilmesine Yönelik Çok Kriterli Bir Yaklaşım: Entropi-ARAS Bütünleşik Modeli

Öz

Çalışmanın amacı, Türkiye'deki özel sermayeli bankaların kurumsal sürdürülebilirlik performanslarını analiz etmektir. Bu amaçla Entropi-ARAS bütünleşik modeli önerilmiştir. Önerilen modelinin etkinliğini kontrol etmek için ayrıca duyarlıık analizi yapılmıştır. Çalışmanın bulgularına göre özel sermayeli bankaların sürdürülebilirlik performanslarının belirlenmesinde en önemli boyut sosyal boyuttur. Kurumsal sürdürülebilirlik bakımından yüksek performans hedefine ulaşmak isteyen bankalar, öncelikle personel devir hızını düşürmeli, ardından doğrudan sera gazı tüketimini azaltmalıdırlar. Çalışma ayrıca, önerilen modelin bankaların kurumsal sürdürülebilirlik performanslarının belirlenmesinde yararlanılabilecek kullanışlı ve güçlü bir karar aracı olduğu ortaya koymuştur.
\end{abstract}

Anahtar kelimeler: Kurumsal sürdürülebilirlik, sürdürülebilirlik performansı, ÇKKV, entropi, ARAS.
A Multi-criteria Approach Towards Assessing Corporate Sustainability Performances of Privately-owned Banks: Entropy-ARAS Integrated Model

Abstract

The aim of this study is to analyze the corporate sustainability performance of privately-owned banks in Turkey. For this aim, the Entropy-ARAS integrated model is proposed. A sensitivity analysis is conducted to check the effectiveness of the proposed model as well. According to the findings, the most important dimension in determining the sustainability performance of privately-owned banks is the social dimension. The banks that desire to achieve high performance in terms of corporate sustainability should first reduce their turnover rate and then reduce their direct greenhouse gas consumption. Moreover, this study revealed that the proposed model is a useful and powerful decision tool and can be utilized in determining the corporate sustainability performance of banks.

Keywords: Corporate sustainability, sustainability performance, MCDM, entropy, ARAS.

\section{Giriş}

Günümüzde paydaşlar şirketlerden sosyal ve çevresel sorumluluklarını yerine getirmelerini beklemekte ve şirketlerin sosyal ve çevresel sorunları nasıl ele aldıkları hakkında bilgi vermelerini istemektedirler. Ayrıca paydaşlar şirketlerin iş performanslarına daha çok odaklanır olmuşlar ve bu konuda baskılarını arttırmışlardır. Bunun doğal sonucu olarak şirketler bu baskılara, sürdürülebilirlik ilkesi çerçevesinde sosyal ve çevresel raporları açıklayarak cevap vermeye başlamışlardır.

Bankalar, ekonomik sistemin yapıtaşlarıdır ve sürdürülebilir kalkınma sürecinin başarılmasında büyük öneme sahiptirler. Bankalardan beklenen sürdürülebilirliği kendi kurumsal stratejilerine entegre etmeleri, çevreye saygılı olmaları, topluma daha üst düzeyde katkıda bulunmaları ve paydaşlarla ilişkilerde şeffaflığa önem vermeleridir (Özçelik ve Avcı Öztürk, 2014). Sürdürülebilirliği kurumsal stratejiye dahil etmek, sürdürülebilirlik stratejisinin performans değerlendirmesi için sürdürülebilirlik bilincinin ve firmaların sürdürülebilirlik artışına yönelik faaliyetlerinin gerekliliğini ortaya koymaktadır (Goyal vd., 2013). Ölçülmesi gereken şey sürekli değiştiği için organizasyonel performansın ölçülmesi daha karmaşık ve zor hale gelmektedir. Şirketlerin

\footnotetext{
${ }^{1}$ Bu çalışma Afyon Kocatepe Üniversitesi Bilimsel Araştırma Projeleri Komisyonu tarafından desteklenen 18.KARIYER.26 numaralı projeden türetilmiştir.

2 Doç. Dr., Afyon Kocatepe Üniversitesi, IïB, İşletme Bölümü. fatihecer@gmail.com, yazar ORCID bilgisi: http://orcid.org/0000-0002-6174-3241.
} 
sürdürülebilirliğe yönelik performanslarını ölçmek için matematiksel modeller kullanmaya ihtiyaç vardır (Özçelik ve Avcı Öztürk, 2014).

Performans değerlendirme, hissedarlar, müşteriler, yöneticiler ve yatırımcılar açısından önemlidir. Performans değerlendirmesinin temel amacı, mevcut kaynakların verimli bir şekilde kullanılıp kullanılmadığını tespit etmektir (Ecer vd., 2011; Ulutagay vd., 2015). Günümüzün yoğun rekabet ortamında, bir şirketin performans değerlendirmesi sadece finansal göstergelere dayanarak yapılamaz. Toplumun çevresel ve sosyal konularda bilinçlenmesi, çevresel ve sosyal performans ölçütlerini de dikkate almayı gerektirmektedir. Dolayısıyla, piyasa ve rekabet koşullarındaki değişiklikler paralelinde, yöneticiler artık ekonomik hedeflerin yanı sıra finansal olmayan performans hedeflerini de göz önünde bulundurmaktadırlar (Özçelik ve Avcı Öztürk, 2014). Bir şirketin kurumsal sürdürülebilirlik performansı genellikle sürdürülebilirliğin üç boyutunu değerlendirerek ölçülür: ekonomik, sosyal ve çevresel performans. Ekonomik performans, bir şirketin yıllık mali raporunda geleneksel olarak bildirilen konuları ve insan sermayesi, araştırma ve geliştirme, ücretler ve yardımlar vb. gibi yatırımları kapsar. Ölçümü ekonomik ve çevresel performanstan daha zor olan sosyal performans; çalışan ilişkileri, sağıık ve güvenlik, ücretlerin yaşama maliyetine oranı, ayrımcılık yapmama, personel devir hızı, eğitim vb. gibi şirketlerin faaliyet gösterdikleri topluluklar üzerindeki etkilerini ifade eder. Çevresel performans ise şirketlerin enerji, toprak, su gibi faaliyetlerinde kullandıkları kaynak miktarını ve hava emisyonları, kimyasal artıklar ve atık su gibi faaliyetlerinin sonuçlarını kapsamaktadır (Hubbard, 2009; Goel, 2010). Bahsedilen performans ölçütleri çerçevesinde şirketlerin performansının ölçülmesi kolay bir iş değildir, çünkü pek çok nitel ve nicel kriter söz konusudur. Ayrıca, çeşitli değerlendirme kriterleri birbiriyle uyuşmayabilmekte ve genel performansı değerlendirmeyi daha zor hale getirebilmektedir. Dolayısıyla kurumsal sürdürülebilirlik performansının ölçümü aslında çok kriterli karar verme (ÇKKV) problemidir. Zor ve karmaşık problemleri çözüme ulaştırma yeteneğine sahip olan ÇKKV yöntemleri (Ecer, 2015), kurumsal sürdürülebilirlik performansının belirleyicilerini tespit etmek, bankaların kurumsal sürdürülebilirlik performansını değerlendirmek ve bankaları performanslarına göre sıralamak için de oldukça uygun araçlardır.

Son yıllara kadar yapılan çalışmalarda bankaların performans değerlendirmesi çoğunlukla sadece finansal veriler kullanılarak yapılsa da günümüzün rekabetçi ortamı ekonomik etkilerin yanında sosyal ve çevresel sonuçların da dikkate alınmasını gerekli kılmaktadır. Sonuç olarak çalışmanın amacı, ülkemizdeki özel sermayeli bankaların sürdürülebilirlik performanslarını entropi temelli ARAS (Additive Ratio ASsessment- Eklemeli Nispi Değerlendirme) modeli ile belirlemektir. Bu çalışmada öncelikle bankaların ekonomik, sosyal ve çevresel boyutlara ait göstergeler karar kriterleri olarak dikkate alınmış ve kriterlerin önem ağılıkları objektif ağırlıklandırma yöntemlerinden biri olan entropi yöntemi ile elde edilmiştir. Böylece sübjektif yapıdaki uzman görüşlerinden kaçınılarak objektif değerlendirmelerin yapılması ve nihai sonuçların elde edilmesi hedeflenmiştir. Bu çerçevede 17 kriterin önem ağırlıkları hesaplanmıştır. Daha sonra ise elde edilen önem ağırıkları ARAS yönteminde kullanılarak bankaların kurumsal sürdürülebilirlik performansları belirlenmiştir. Bu çalışmanın literatüre iki önemli katkısının olacağı düşünülmektedir. Çalışmanın katkılarından biri, sadece sürdürülebilirlik raporlarının içerik analiziyle incelenmesi suretiyle kurumsal sürdürülebilirlik performansının belirlendiği çoğu çalışmanın aksine, bu çalışmada uzman görüşlerine ihtiyaç duyulmaksızın gerek sürdürülebilirlik raporlarından gerekse de Türkiye Bankalar Birliği'nden (TBB) sağlanan veriler kullanılarak çok kriterli bir modelinin önerilmesidir. Çalışmanın bir diğer önemli katkısı ise, bankaların kurumsal sürdürülebilirlik performanslarında etkili olan kriterlerin ağırlıklarının objektif olarak belirlenmesidir. 
Çalışma şu şekilde organize edilmiştir. Sonraki bölümde kısaca kurumsal sürdürülebilirlik konusu ele alınmıştır. Üçüncü bölümde kurumsal sürdürülebilirlik performansının ölçümüne yönelik yapılmış çalışmalara yer verilmiştir. Önerilen bütünleşik modelin ana bileşenleri olan entropi ve ARAS yöntemlerine dördüncü bölümde değinilmiştir. Beşinci bölümde yapılan uygulama ortaya konulmuş, elde edilen sonuçlar üzerinde değerlendirmeler yapılmış ve son olarak duyarlılık analizi gerçekleştirilerek modelin etkinliği ve geçerliliği analiz edilmiştir. Çalışma, sonuç bölümü ile tamamlanmıştır.

\section{Kurumsal Sürdürülebilirlik}

Son yıllarda sürdürülebilirliğin iş dünyasında büyük önem kazandığı görülmektedir. Sürdürülebilir kalkınma kavramı, ilk kez 1987 yılında Dünya Çevre ve Kalkınma Komisyonu (WCED) tarafından yayınlanan ve Brundtland raporu olarak da bilinen "Ortak Geleceğimiz" raporunda kullanılmıştır. Raporda sürdürülebilir kalkınma, gelecek nesillerin kendi ihtiyaçlarını karşılayabilme yeteneğinden ödün vermeden, bugünün ihtiyaçlarını karşılayan bir kalkınma olarak tanımlanmaktadır. Elkington (1997) ise ilk olarak üçlü performans raporlaması (Triple Bottom Line-TBL) kavramını kurumsal sürdürülebilirliğin ekonomik, sosyal ve çevresel boyutlarının bir parçası olarak nitelendirmiştir (Aras vd., 2017).

Kurumsal sürdürülebilirlik, şirketlerdeki tüm paydaşlara uzun vadeli ve kalıcı değer oluşturmak için ekonomik, çevresel ve sosyal faktörlerin şirket faaliyetlerine ve karar alma süreçlerine adaptasyonudur (Aras vd., 2018). Dolayısıyla kurumsal sürdürülebilirlik, büyüme ve karlılığın önemine vurgu yaparken, aynı zamanda çevrenin korunması, sosyal adalet ve eşitliğin sağlanması ve ekonomik kalkınmanın gerçekleştirilmesi gibi toplumsal amaçları da göz önünde bulundurmayı gerektirir. Ayrıca, işletmelerde kurumsal sürdürülebilirliğin başarılı olabilmesi için hem hükümet, müşteriler ve toplum gibi dış faktörlerin hem de yönetimin bakış açısı, çalışanların eğitimi gibi iç faktörlerin sürece uyum sağlaması gerekmektedir (Alp vd., 2015).

Sürdürülebilirlik çabaları ve uygulamaları, kamuya açık raporlar aracılığıyla ortaya konulur. Sürdürülebilir raporları olarak adlandırılan raporlar, şirketlerin iç ve dış paydaşlarına kurumsal yapı ile ekonomik, çevresel ve sosyal boyutlardaki faaliyetlerin bir resmini sunmaları için oluşturulmuş raporlardır. Sürdürülebilirlik raporlaması, üçlü performans raporlaması, kurumsal sosyal sorumluluk raporlaması ve sosyal sorumluluk raporlaması eş anlamlı olarak kullanılmaktadır (Roca ve Searcy, 2012; Aras vd., 2017). Finansal olmayan bir raporlama türü olan sürdürülebilirlik raporlaması, işletmenin örgütsel performansı hakkında paydaşlara açıklama yapma ve hesap verme sorumluluğu olarak görülebilir. Sürdürülebilirlik raporlaması, işletmelerin daha şeffaf ve daha yüksek bir düzeyde hesap verebilirlik seviyesine ulaştı̆̆ını gösterir (Özçelik ve Avcı Öztürk, 2014). Sürdürülebilirlik raporları, finansal/ekonomik, sosyal/etik ve çevresel performans hakkında niceliksel ve niteliksel bilgileri içermektedir. Bununla birlikte sürdürülebilirlik raporları yayımlamak zorunlu değildir, gönüllülük esasına göre hazırlanırlar (Hu vd., 2011). Gelişmekte olan ülkelerde sürdürülebilirlik raporları yayımlanmaktadır, fakat farkındalık sınırlıdır. Türkiye'de son yıllarda bazı şirketler sürdürülebilirlik raporlarını iş stratejilerine dahil etmeye başlamıştır ve bu raporları sürdürülebilirlik raporları, kurumsal sosyal sorumluluk raporları gibi isimlerle Küresel Raporlama Girişimi'nin (Global Reporting Initiative-GRI) sürdürülebilirlik raporlama ilkelerine göre raporlamaktadırlar. Ancak Türkiye'de oransal olarak çok az sayıda şirketin sürdürülebilirlik raporu hazırladığı görülmektedir. Ayrıca bazı şirketlerin sürdürülebilirlik raporları GRI göstergelerine dayanmakta iken ve bazıları ise farklı şekillerde hazırlanmaktadır (Özçelik ve Avcı Öztürk, 2014). Son yıllarda yapılan çalışmalar, sürdürülebilirlik konularının şirketler için 
ne kadar önemli olduğunu ve paydaşlara bildirilmesi gereken önemli konuların tespit edilmesine yönelik sektöre özgü kılavuzların şirketlerin hem sürdürülebilirlik performanslarını hem de rapor etme yeteneklerini artırdığını ortaya koymaktadır (Eccles vd., 2015; Atkins ve Maroun, 2015, Aras vd., 2017). Bunlara ilave olarak, sürdürülebilirlik raporu şirketlerin sürdürülebilirlik hedefine ulaşırken sergilediği olumlu ve olumsuz sürdürülebilirlik performanslarını da ifade ederken şirketlere sürdürülebilirlik faaliyetlerinin benimsenmesi ve operasyonel etkilerinin raporlanması, ekonomik büyümenin sürdürülmesi ve yaygınlaştırılması, rekabet gücünün artırılması, hissedar değeri, saygınlık, kurumsal itibar, müşteri memnuniyeti ve sadakat, marka değeri, çalışanların korunması, çalışan motivasyonunun artırılması ve maliyet tasarrufu konularında fayda sağlar. Böylece, sürdürülebilirlik raporlaması risklerin ve fırsatların daha iyi anlaşılmasını sağlar ve olumsuz çevresel, sosyal ve yönetsel etkileri azaltır (Özçelik ve Avcı Öztürk, 2014).

Çoğu batılı ülkeye oranla daha fazla banka yönelimli olan Türk finans sisteminde bu durum bankacılık sektörünün hayati öneme sahip olmasına ve finansal sektörün hakimi olmasına neden olmaktadır. Finansal sektör varıklarının neredeyse tamamı bankalar tarafından yönetildiğinden, bu kurumların yönetim yapısı ve topluma katkıları önemlidir (Akdoğan vd., 2017). Bankaların sürdürülebilirliğe ulaşma süreci dört aşamada gerçekleşir: savunma bankacılığı, önleyici bankacılık, saldırgan bankacılık ve sürdürülebilir bankacılık. Savunma bankacılığı aşamasında, karlılık ve büyüme kaygısı taşıyan bankalar pasif konumda olmayı ve sürdürülebilirliği kaçınılması gereken bir maliyet olarak görmeyi tercih etmektedirler. Önleyici bankacılık aşamasında bankalar, sürdürülebilir operasyonlarda potansiyel maliyet tasarruflarının (enerji ve kâğıt tasarrufu vb.) farkına varmakta ve iç operasyonlarda sürdürülebilirliği dikkate almaktadırlar. Saldırgan bankacılık aşamasında bankalar, sürdürülebilir kalkınma sürecinde (sürdürülebilir finansal ürünler, yeni pazarlar, sürdürülebilir enerjinin finansmanı gibi) fırsatları görmeye başlarlar ve iç operasyonların yanı sıra dış operasyonlarda da sürdürülebilirliği dikkate alırlar. Sürdürülebilir bankacılık aşamasında ise, bankaların tüm operasyonları sürdürülebilir ve çevresel hale gelir; sosyal ve ekonomik sürdürülebilirlik, maksimum finansal getirinin yerini alır (Özçelik ve Avcı Öztürk, 2014).

Bankalar ekonomik sistemde finansal aracılık rolünü üstlendiklerinden bankacılık sektörü petrokimya, madencilik vb. gibi sektörlerle karşılaştırıldığında çevreye en az zarar veren sektörlerin başında gelmektedir. Ancak bankacılığın da içinde yer aldığı finansal kuruluşların doğrudan ve dolaylı şekilde çevresel ve sosyal etkileri vardır. Doğrudan etkiler, dolaylı etkilere nazaran oldukça önemsiz düzeydedir. Su, kağıt, enerji tüketimi vb. ile oluşan atıklar bankaların doğrudan etkileri arasında yer alır. Bankaların dolaylı etkilerinin çevreyi etkilemediğini söylemek doğru gibi görünse de finansal ürünlerin kullanıcılarının aldıkları kredilerle gerçekleştirdikleri faaliyetler ve yatırımlar sonucunda çevreye ve insanlara zarar verebildikleri düşünüldüğünde dolaylı etkilerin doğrudan etkilerden çok daha büyük ve tehlikeli olduğu açıktır (Öner Kaya, 2010).

\section{Literatür Taraması}

Finansal kuruluşların kurumsal sürdürülebilirlik performanslarının belirlenmesine yönelik yapılmış çalışmaların genellikle sadece sürdürülebilirlik raporlarına odaklandığı, nitel verileri içerik analiziyle değerlendirdikleri ve ekonomik, sosyal ve çevresel boyuttaki açıklamaların oransal olarak sürdürülebilirlikte ne kadarlık bir paya sahip olduğuna yönelik değerlendirmeler yaptıkları görülmektedir. 
Örneğin, Öner Kaya (2010) sürdürülebilir bankacılık anlayışının uygulanabilirliğini araştırdığı çalışmasında ekonomik, sosyal ve çevresel sürdürülebilirlik ile ilgili farkındalığın ortaya çıkış sürecini incelemiştir. Ayrıca, bankaların sürdürülebilir kalkınma sürecindeki rollerini ele alarak Türkiye'de sürdürülebilir bankacılığın geldiği noktaya değinmiştir.

Khan vd. (2011), Bangladeş'in büyük ticari bankaların kurumsal sürdürülebilirlik raporlarını GRI ilkeleri çerçevesinde incelemişlerdir. Sonuçlar, toplumla ilgili açıklamaların en kapsamlı şekilde yapılan açıklamalar olduğunu göstermiştir. Bunu, çevre konularında hazırlanan açıklamalar izlemiştir.

Sobhani vd. (2012), Bangladeş'te bankacılık sektörünün yıllık raporlarında ve kurumsal web sitelerinde yer alan kurumsal sürdürülebilirlik göstergelerini analiz etmişlerdir. Çalışmada, Bangladeş'teki bankaların sosyal boyuta ilişkin açıklamalarının çevresel ve ekonomik boyuta ilişkin açıklamalara göre daha fazla olduğu ortaya konulmuştur.

Roca ve Searcy (2012), 94 Kanada firmasının 2008 ile 2011 yılları arasında toplam 584 göstergeyle açıklanan raporlarını inceledikleri çalışmalarında, GRI göstergelerinin kullanımının sektörler arasında biraz farklılık gösterdiği sonucuna ulaşmışlardır.

Saxena ve Kohli (2012), Hint bankacılık sektörünün kurumsal sosyal sorumluluk alanındaki sürdürülebilirlik çabalarını incelemişler ve kurumsal sosyal sorumluluk ile finansal performans arasında zayıf bir bağ olduğunu ortaya koymuşlardır.

Kaderli ve Gündüz (2014), sürdürülebilirlik performansı ile finansal performans arasındaki ilişkiyi tespit etmek amacıyla Akbank özelinde bir çalışma yapmışlardır. Çalışmada elde edilen bulgulara göre bankanın sürdürülebilirlik raporlarında yayımladığı bilgilerle finansal oranlar arasında pozitif yönlü ilişkiler saptanmıştır. Yazarlar bankaların sürdürülebilirlik faaliyetlerini raporlamasının kendileri açısından olumlu sonuçlar ortaya çıkaracağını değerlendirmişlerdir.

Maubane vd. (2014), Johannesburg Menkul Kıymetler Borsası'nda listelenen 74 şirketin sürdürülebilirlik raporlama modellerini araştırmışlardır. İçerik analizi sonuçları, madencilik ve malzeme sektörünün diğer sektörlere göre daha fazla çevresel ve toplumsal raporlamaya sahip olduğunu ortaya koymuştur.

Zahid ve Ghazali (2015), Malezya'daki 90 şirketin kurumsal sürdürülebilirlik uygulanmasını içerik analiziyle incelemişlerdir. İçerik analizi, şirketlerin çoğunluğunun, paydaşların memnuniyeti ve firma uygulamalarını meşru kılmak için sosyal sorumluluk ve sürdürülebilirlik stratejilerine sahip olduğunu göstermiştir. Ayrıca raporlarda çevresel açıklamaların en az, sosyal açıklamaların ise en yüksek açıklama oranına sahip olduğu bulunmuştur.

Weber (2016), yıllık finansal ve finansal olmayan raporlardan elde edilen verileri değerlendirerek Çin bankalarının sürdürülebilirlik performansını analiz etmiştir. Weber'in çalışmasında ayrıca kurumsal sürdürülebilirlik performansı ile finansal performans arasındaki ilişki de araştırılmıştır.

Nobanee ve Ellili (2016) çalışmalarında Birleşik Arap Emirlikleri borsasında işlem gören bankaların yıllık verilerinden yararlanarak kurumsal sürdürülebilirlik açıklamalarını incelemişlerdir. Sürdürülebilirlik raporlarının açıklanmasıyla bankacılık performansı arasındaki ilişkiyi test etmek için panel veri analizi kullanmışlardır.

Weber (2017) yaptığı çalışmada, bankacılık sektörünün finansal performansını düşürmeden sürdürülebilirlik düzenlemelerinin uygulanıp uygulanmayacağını araştırmak için Çin bankaları- 
nın sürdürülebilirlik performansı ile finansal göstergeleri arasındaki bağlantıyı incelemiştir. Çaıışmanın sonuçları, Çin bankalarının çevresel ve sosyal performansının 2009 ile 2013 yılları arasında önemli ölçüde arttığını göstermiştir. Ayrıca, Çin bankalarının finansal performansı ile sürdürülebilirlik performansı arasında iki yönlü bir nedensellik bulunmuştur.

Hussain vd. (2018), kurumsal yönetim ve sürdürülebilirlik performansı arasındaki ilişkiyi üçlü performans raporlaması çerçevesinde ampirik olarak incelemişlerdir. Çalışmada, ABD merkezli 100 şirketin 2007-2011 arasındaki sürdürülebilirlik raporlarından yararlanılarak içerik analizi yapılmıştır.

Kumar vd. (2018), en iyi 10 Hint bankasının sürdürülebilirlik raporlama uygulamalarını içerik analiziyle incelemişlerdir. Çalışmada elde edilen önemli bir bulgu, en iyi 10 Hint bankasının çoğunun henüz sürdürülebilir raporlamada yeterli bilgilendirme yapmadığı ve şeffaflık uygulamalarını benimsemediği olmuştur. Diğer bulguya göre, çevresel ve sosyal açıklamalar geniş bir şekilde raporlansa bile, "eşit ücret", "iş sağlığı ve güvenliği" ve "müşteri gizliliği" gibi ölçütlerde göze çarpan eksiklikler tespit edilmiştir.

Kılıç ve Kuzey (2018), mevcut raporların Uluslararası Entegre Raporlama Konseyi (IIRC) bütünleşik raporlama çerçevesine bağlılık düzeyini, bu raporların içerik çerçevesini kapsayıp kapsamadığını ve kapsıyorsa ne ölçüde kapsadığını içerik analiziyle araştırmışlardır. Çalışmada, bütünleşik raporlama açıklamasının sürdürülebilirlik raporlaması, GRI adaptasyonu, sürdürülebilirlik endeksi listesi ve bir sürdürülebilirlik komitesinin varlığıyla anlamlı ve pozitif ilişkili olduğunu bulunmuştur.

Aras vd. (2018) çalışmalarında ekonomik, sosyal ve çevresel boyutların yanına, yönetsel ve finansal boyutları da ekleyerek yeni bir kurumsal sürdürülebilirlik modeli önermişlerdir. Çalışmada, Türkiye'deki 3'ü kamu, 7'si özel banka olmak üzere kamu ve özel bankalar arasında kurumsal sürdürülebilirlik açısından bir karşılaştırma yapılmıştır. Çalışmanın sonuçları özel bankaların yönetsel ve finansal boyutlarda, kamu bankalarının ise diğer 3 boyutta daha etkin olduğunu göstermiştir.

Literatürde ÇKKV yöntemleri kullanılarak kurumsal sürdürülebilirlik performansı ölçen çaıışma sayısının oldukça az olduğu dikkat çekmektedir. Bu çalışmalardan birinde Özçelik ve Avcı Öztürk (2014), kurumsal sürdürülebilirlik raporlarını kullanarak seçilmiş bankaların kurumsal sürdürülebilirlik performansını gri ilişkisel analiz (GIA) yöntemini kullanarak ölçmüşlerdir. Sürdürülebilirlik performansına göre bankalar sırasıyla TSKB, Garanti Bankası ve Akbank şeklinde sıralanmışlardır.

Goyal vd. (2015), kurumsal sürdürülebilirlik uygulamalarını AHP yöntemini kullanarak değerlendirmişlerdir. Analiz sonuçlarına göre, kurumsal sürdürülebilirlik performansının iyileştirilmesinde piyasa değeri, çevre yönetimi ve stratejisi, araştırma ve geliştirme, kirlilik önleme, kurumsal yönetim ve yatırımcı sorumluluğu uygulamalarının en önemli uygulamalar olduğu belirlenmiştir.

Alp vd. (2015), bir firmanın kurumsal sürdürülebilirlik performansını ölçmek amacıyla entropi temelli MAUT yönteminden yararlanmışlardır. Çalışmada şirketin 2009-2013 yılları arasındaki sürdürülebilirlik raporlarından derlenen $38^{\prime} i$ sosyal, 2 'si ekonomik ve $31^{\prime} i$ ise çevresel boyutlarda olmak üzere toplam 90 göstergeden yararlanılmıştır. 
Rebai vd. (2016), bankacılık sürdürülebilirlik endeksi oluşturmak için bir sürdürülebilirlik performans değerlendirme modeli geliştirmişlerdir. 3 ticari Fransız bankasının performans değerlendirilmesi aşamasında AHP yöntemi kriterlerin önem ağırlıklarının belirlenmesinde kullanılmıştır.

Aras vd. (2016) yaptıkları çalışmada Türkiye'de sürdürülebilirlik raporu yayımlayan geleneksel bankalar ile katılım bankalarının sürdürülebilirlik performansını entropi temelli TOPSIS yöntemini kullanarak karşılaştırmışlardır. Çalışmanın sonucunda geleneksel bankalar ile katılım bankalarının sürdürülebilirlik performanslarının birbirine yakın olduğu bulunmuştur.

Ömürbek vd. (2017), Türkiye'deki büyük ölçekli 7 bankanın sürdürülebilirlik performanslarını 13 kritere göre değerlendirmişler ve farklı ÇKKV yöntemleri kullanarak analiz etmişlerdir. Elde edilen sonuçlara göre en iyi performansı Ziraat Bankası göstermiştir. Bu sonucun ortaya çıkmasında sosyal faktöre bağlı olan ve yüksek değer almasının iyi olduğu kriterlerin yüksek, çevresel faktör altında yer alan ve düşük değer almasının daha iyi olduğu kriterlerin ise düşük olmasının etkili olduğu değerlendirilmiştir.

Korzeb ve Samaniego-Medina (2019) Polonya'daki ulusal ve yabancı sermayeli bankaların sürdürülebilirliklerini analiz etmişler ve bu amaçla TOPSIS yöntemini kullanmışlardır. Elde edilen bulgular, ulusal bankaların yabancı sermayeli bankalara nazaran sürdürülebilirlik uygulamalarını daha fazla desteklediklerini ortaya koymuştur.

Yapılan literatür incelemesi sonucunda sürdürülebilirlik performansının ölçümü ve değerlendirilmesi konusunda henüz yeterli sayıda çalışmanın yapılmadığı, bu nedenle gerek Türkiye'de gerekse de dünyada daha fazla çalışmanın yapılması gerektiği görülmektedir. Özellikle son yıllarda bankaların faaliyetleri süresince sadece ekonomik performansı değil aynı zamanda çevresel ve sosyal performansı da gözeterek bu konulara önem vermeye başlamaları bilimsel çalışmalar için kullanışı verilerin ortaya çıkmasına neden olmaktadır. Diğer taraftan gerek bu verilerin işlenmesindeki zorluklar gerekse de sürdürülebilirlik performansının ölçümünün kapsamlı ve titiz bir yaklaşım gerektirmesi bu alanda üretilen çalışmaları daha önemli kılmakta ve değerini arttırmaktadır. Sonuç olarak bu çalışma bankaların sürdürülebilirlik performanslarını önerilen bir ÇKKV modeliyle ölçmeye odaklanmaktadır ve literatürdeki boşluğu dolduracağı düşünülmektedir.

\section{Yararlanılan Yöntemler}

Çalışmanın amacı özel sermayeli bankaların kurumsal sürdürülebilirlik performanslarını ölçmektir. Bu amaçla bankaların yayımladıkları sürdürülebilirlik raporlarındaki verilerden ve TBB'nin derlediği verilerden yararlanılmıştır. Ekonomik, sosyal ve çevresel boyutlardaki göstergeler kriter olarak değerlendirilerek, kriterlerin önem ağırlıkları uzman görüşüne ihtiyaç duyulmadan ağırlık belirlemeye yarayan ve objektif bir yöntem olan entropi yöntemiyle elde edilmiştir. Daha sonra bulunan ağırıklar yeni bir ÇKKV yöntemi olan ARAS yönteminde kullanılarak gerekli analizler yapılmış ve bankaların sürdürülebilirlik performans puanları ve sıralamaları elde edilmiştir. Bu entegre modelin avantajı, bir yandan entropi sayesinde uzmanların öznelliğinin ortadan kaldırılması iken diğer taraftan ARAS'ın ideal alternatife göre oransal benzerlikleri kullanması neticesinde en uygun seçimin yapılabilmesidir. Bu bölümde kısaca entropi ve ARAS yöntemlerinden bahsedilecektir.

\subsection{Entropi Yöntemi}

Kriter ağırlıkları, ÇKKV problemlerinde elde edilen sıralamalar üzerinde kritik öneme sahiptir. Çünkü değerlendirme ve seçim süreçleri sonucunda bulunan alternatif sıralamaları, kriter 
ağırıklarından doğrudan etkilenir. Kriter ağırlıkları öznel ya da nesnel olarak elde edilebilir. Bu çalışmada kriter ağırlıklarının belirlenmesinde nesnel ağırlık yöntemlerinden biri olan Entropi yönteminden faydalanılmıştır. Böylece karar vericilerin kişisel tercihlerinden ziyade objektif bir değerlendirme yapılması amaçlanmıştır.

Entropi kavramı, ilk olarak Shannon (1948) tarafından ortaya atılan bir kavramdır. Bilgi, düzenli dereceyi temsil ederken entropi düzensizliği ifade eder. Eğer bir nesne düşük entropiye sahipse indeks değerindeki değişim yüksektir ve ağırlığı büyüktür. Aksi durumda yani bir nesnenin yüksek entropi değeri olduğunda indeks değerinin değişimi küçüktür ve dolayısıyla ağırlığı da küçüktür. Dolayısıyla, entropi değeri indeks değerindeki değişime göre hesaplanabilir. Böylece, tüm indekslerin ağırlıklandırıması hesaplanmakta ve daha sonra kapsamlı değerlendirmenin objektif bir sonucu elde edilmektedir (Wei, 2016; Sun, 2014). Entropi yönteminde kriter önem ağırlıklarını hesaplamak için aşağıdaki adımlar izlenir (Li vd., 2011; Sun, 2014).

Adım 1. Karar matrisinin belirlenmesi

$m$ sayıda alternatife ve $n$ sayıda kritere sahip bir ÇKKV probleminin karar matrisi aşağıdaki gibi gösterilmektedir.

$$
A=\left[\begin{array}{cccc}
x_{11} & x_{12} & \cdots & x_{1 n} \\
x_{21} & x_{22} & \cdots & x_{2 n} \\
\vdots & \vdots & \ddots & \vdots \\
x_{m 1} & x_{m 2} & \cdots & x_{m n}
\end{array}\right]
$$

Burada $x_{i j}(i=1,2, \ldots, m ; j=1,2, \ldots, n) i$. alternatifin $j$. kritere göre performans değeridir.

Adım 2. Standartlaştırma

Ölçüt boyutunun ölçülemezlik üzerindeki etkisini ortadan kaldırmak için, göreceli optimum üyelik derecesinin denklemlerini kullanarak ölçütleri standartlaştırmak gerekir. Fayda ile ilgili kriterler ve maliyete ilişkin kriterler için normalize edilmiş değerler aşağıdaki gibi hesaplanır:

$$
\begin{aligned}
& r_{i j}=x_{i j} / \max _{j} x_{i j},(i=1,2, \ldots, m ; j=1,2, \ldots, n) \\
& r_{i j}=\min _{j} x_{i j} / x_{i j}, \min _{j} x_{i j} \neq 0,(i=1,2, \ldots, m ; j=1,2, \ldots, n)
\end{aligned}
$$

Böylece, standartlaştırmanın ardından $R=\left[r_{i j}\right]_{m x n}$ standart karar matrisi elde edilir.

Adım 3. Entropinin hesaplanması

$f_{i j}$ normalize edilmiş değerleri göstermek üzere $f_{i j}=\frac{r_{i j}}{\sum_{i=1}^{m} r_{i j}}$ formülü ile hesaplanır. Bilgi kuramına göre $j$. kriterin entropisi aşağıdaki denklemdeki gibidir.

$$
e_{j}=-\frac{\sum_{i=1}^{m} f_{i j} \ln f_{i j}}{\ln m}, \quad(i=1,2, \ldots, m ; j=1,2, \ldots, n)
$$

Adım 4. Entropi ağırlı̆̆ının hesaplanması

$j$. kriterin entropi ağırlığı aşağıdaki denklemle bulunur. 


$$
w_{j}=\frac{1-e_{j}}{n-\sum_{j=1}^{n} e_{j}},
$$

\subsection{ARAS Yöntemi}

Çalışmada bankaların sürdürülebilirlik performanslarını belirlemek için ARAS yöntemi kullanılmıştır. ARAS yöntemi basit, etkili ve oldukça yeni bir ÇKKV metodudur (Ecer, 2018). ARAS yöntemine göre bir projede olası bir alternatifin göreli etkinliğini belirlemekte kullanılan fayda fonksiyonu, kriterlerin ağırlık ve değerlerinin göreli etkileri ile orantılıdır. Yöntemin en belirgin özelliği, alternatiflerin fayda fonksiyonu değerlerinin optimal alternatife ait fayda fonksiyonu değeri karşılaştırılmasıdır. ARAS yöntemi alternatifin performansını belirlemeye yardımcı olur ve her alternatifin ideal alternatife göre oransal benzerliğini ortaya koyar (Dadelo vd., 2012). Örneğin bir kriterin optimal değerinin 10 olduğunu, ancak bu kritere göre değerlendirmede alternatifler arasındaki en büyük skorun 9 olduğunu kabul edelim. Bu durumda kriterin optimallik değeri diğer ÇKKV yöntemlerinde olduğu gibi 10 değil 9'dur. Böylece ARAS yöntemi diğer ÇKKV yöntemleri arasında oransal derecelendirme amacına en uygun olan yöntem gibi görünmektedir (Ecer, 2016).

ARAS yöntemi ile 5 adımda sonuca ulaşılır (Dadelo vd., 2012; Ecer, 2016):

Adım 1. Karar matrisinin oluşturulması

Öncelikle karar matrisi oluşturulur. ÇKKV problemlerinde karar matrisi aşağıdaki gibidir.

$$
X=\left[\begin{array}{cccc}
x_{01} & x_{02} & \cdots & x_{0 n} \\
x_{11} & x_{12} & \cdots & x_{1 n} \\
\vdots & \vdots & \cdots & \vdots \\
x_{m 1} & x_{m 2} & \cdots & x_{m n}
\end{array}\right] \quad i=0,1, \ldots, m ; j=0,1, \ldots, n
$$

Matriste $m$ alternatif sayısını, $n$ kriter sayısını, $x_{i j} j$ kriterine göre $i$ alternatifinin performans değerini ve $x_{0 j}$ ise $j$ kriterinin optimal değerini göstermektedir. Eğer $j$ kriterinin optimal değeri bilinmiyorsa (7) numaralı formül kullanılır:

$$
\left\{\begin{array}{l}
\text { Ĕger } \operatorname{maks}_{i} x_{i j} \text { ise } x_{0 j}=\operatorname{maks}_{i} x_{i j} \\
\text { Eğer } \min _{i} x_{i j}^{*} \text { ise } x_{0 j}=\min _{i} x_{i j}^{*}
\end{array}\right.
$$

(7) numaralı formülden dikkate alınan kriterin fayda kriteri ya da maliyet kriteri olmasına göre yararlanılır. Fayda kriterlerinde maksimizasyon, maliyet kriterlerinde ise minimizasyon kullanilır.

Adım 2. Normalizasyon

Genellikle değerlendirmelerde yararlanılan kriterler farklı boyutlarda ve ölçeklerde olabilmektedir. Bu adımın amacı farklı boyutlarda olan kriterleri normalizasyon işlemi gerçekleştirerek standart hale getirmektir. Böylece tüm kriterler $[0,1]$ aralığında değerlere sahip olur. Normalizasyonda fayda kriterleri için Formül (8), maliyet kriterleri için ise Formül (9) kullanılır.

$$
\bar{x}_{i j}=\frac{x_{i j}}{\sum_{i=0}^{m} x_{i j}}
$$




$$
\bar{x}_{i j}=\frac{1 / x_{i j}}{\sum_{i=0}^{m} 1 / x_{i j}}
$$

Normalizasyon işleminin ardından normalize edilmiş karar matrisi şöyle oluşturulur:

$$
\bar{X}=\left[\begin{array}{cccc}
\bar{x}_{01} & \bar{x}_{02} & \ldots & \bar{x}_{0 n} \\
\bar{x}_{11} & \bar{x}_{12} & \ldots & \bar{x}_{1 n} \\
\vdots & \vdots & \ldots & \vdots \\
\bar{x}_{m 1} & \bar{x}_{m 2} & \ldots & \bar{x}_{m n}
\end{array}\right] ; i=0,1, \ldots, m ; j=0,1, \ldots, n
$$

Adım 3. Ağırıklandırılmış normalize karar matrisinin oluşturulması

Bu adımda ağılıklandırılmış normalize karar matrisi elde edilir. Kriter ağılıkları 0 ile 1 arasında bir değer alır $\left(0<w_{j}<1\right)$. Ayrıca kriter ağılıklarının toplamı 1'e eşittir. Ağırlıklar analiz sonuçlarını doğrudan etkilediği için ağırlıkların titiz ve dikkatlice belirlenmesi büyük önem taşımaktadır. Ağırlıklı normalize değerler Formül (11) ile belirlenir. Formülde $w_{j}, j$ kriterinin önem ağırlığını, $\bar{x}_{i j}$ ise $j$ kriterinin normalize edilmiş değerini ifade etmektedir.

$\hat{x}_{i j}=\bar{x}_{i j} w_{j} ; \quad i=0,1, \ldots, m$

Böylece ağırlıklandırılmış normalize karar matrisi aşağıdaki gibi oluşturulur:

$$
\hat{X}=\left[\begin{array}{cccc}
\hat{x}_{01} & \hat{x}_{02} & \cdots & \hat{x}_{0 n} \\
\hat{x}_{11} & \hat{x}_{12} & \cdots & \hat{x}_{1 n} \\
\vdots & \vdots & \cdots & \vdots \\
\hat{x}_{m 1} & \hat{x}_{m 2} & \cdots & \hat{x}_{m n}
\end{array}\right] ; i=0,1, \ldots, m ; j=0,1, \ldots, n
$$

Adım 4. Si optimallik fonksiyonunun hesaplanması

$$
\sum_{j=1}^{n} \hat{x}_{i j} ; \quad i=0,1, \ldots, m
$$

(13) numaralı formülde $S_{i}, i$ alternatifinin optimallik fonksiyonudur. $S_{i}$ değeri ne kadar büyükse o kadar iyidir şeklinde yorumlanabilir. Çünkü hesaplama süreci göz önünde bulundurulduğunda $S_{i}$, nihai sonucu etkileyen $x_{i j}$ ve $w_{j}$ değerleriyle doğrudan ilişkilidir. Sonuç olarak $S_{i}$ değeri büyük olan alternatif daha etkin alternatiftir.

Adım 5. Fayda derecesinin hesaplanması ve sıralamanın elde edilmesi

Fayda derecesi, bir alternatifin optimallik fonksiyonu değeri ile en iyi alternatifin optimallik fonksiyonu değerinin kıyaslanması neticesinde bulunur. So, en iyi optimallik fonksiyonu değeri iken hesaplama (14) numaralı formül kullanılarak yapılır.

$$
K_{i}=\frac{s_{i}}{S_{0}} \quad ; i=0,1, \ldots, m
$$

Son yıllarda ARAS yönteminin personel seçimi (Karabasevic vd., 2016), kurumsal kaynak planlaması seçimi (Ecer, 2016), yeşil tedarikçilerin değerlendirilmesi ve seçimi (Liao VD., 2016), mobil bankacılık hizmetlerinin değerlendirilmesi (Ecer, 2018), ülkelerin yaşam kalitelerinin değerlendirilmesi (Ömürbek vd., 2017) ve hizmet kalitesi değerlendirilmesi (Bakır ve Atalık, 2018) gibi işletmecilik alanında pek çok farklı problemin çözümünde kullanıldığı görülmektedir. 


\section{Uygulama}

Bir kuruluşun ekonomik performansı, kuruluşun ve onun sürdürülebilirlik temelinin anlaşıması için esastır. Ekonomik sürdürülebilirlik, bir kuruluşun faaliyetlerinin ekonomik sonuçlarını ve bu sonuçların geniş bir paydaş yelpazesine etkisini ölçmeyi amaçlamaktadır. Çevresel sürdürülebilirlik, bir kuruluşun ekosistem, toprak, hava ve su dahil olmak üzere doğal sistemler üzerindeki etkisi ile ilgilidir. Çevresel sürdürülebilirlik, girdi (malzeme, enerji, su) ve çıktı (emisyonlar, atık sular, atık) ile ilgili performansı kapsar. Ayrıca, biyoçeşitlilik, çevresel uyumluluk ve çevresel harcama ile ürün ve hizmetlerin etkileri gibi diğer ilgili bilgileri içeren performansları içerir. Sürdürülebilirliğin sosyal boyutu ise bir kuruluşun faaliyet gösterdiği sosyal sistemler üzerindeki etkisiyle ilgilidir (Sobhani vd., 2012). Özetle söylemek gerekirse bir kuruluşun sürdürülebilirlik performansının ölçülmesinde ekonomik, çevresel ve sosyal sürdürülebilirlik boyutlarının ve bunlara ilişkin göstergelerin ele alınması gerekmektedir.

Sürdürülebilirlik kriterlerinin belirlenmesi amacıyla bu çalışmada mevcut literatür taranmış (Tablo 1), GRI raporlama çerçevesi ile Birleşmiş Milletler Çevre Programı Finans Girişimi göz önünde bulundurulmuş ve uzman kişilerin görüşlerine başvurulmuştur. Böylece Türk bankacılık sektörüne uygun olan, GRI G3 ve GRI G4 raporlama kılavuzları kriterlerinden ve TBB'den 5 'i ekonomik, 6'sı sosyal ve 6'sı da çevresel boyutta olmak üzere toplam 17 gösterge kriter olarak belirlenerek analizler gerçekleştirilmiştir (Şekil 1).

Tablo 1: Sürdürülebilirlik Performansının Belirlenmesi Amacıyla Kullanılmış Olan Kriterler

\begin{tabular}{|c|c|}
\hline Yazar/lar & Değerlendirme kriterleri \\
\hline Khan (2011) & $\begin{array}{c}\text { Doğrudan enerji tüketimi, dolaylı enerji tüketimi, su tüketimi, doğrudan sera gazı salı- } \\
\text { nımı, dolaylı sera gazı salınımı, çalışan sayısı, çalışan devir hızı, eğitim süresi }\end{array}$ \\
\hline Sobhani vd. (2012) & Enerji tasarrufu, enerji projelerine yatırım, enerji tüketimi, sera gazı salınımları \\
\hline $\begin{array}{l}\text { Özçelik ve Avcı Öz- } \\
\text { türk (2014) }\end{array}$ & $\begin{array}{l}\text { Sermaye yeterlilik oranı, özkaynak karlılığı, aktif getiri oranı, elektrik tüketimi, su tüke- } \\
\text { timi, kağıt tüketimi, } \mathrm{CO}_{2} \text { emisyonu, çalışan devir hızı, eğitim süresi }\end{array}$ \\
\hline Alp vd. (2015) & $\begin{array}{l}\text { Faaliyet karı, özkaynak oranı, elektrik tüketimi, doğalgaz tüketimi, su tüketimi, diğer } \\
\text { enerji tüketimi, } \mathrm{CO}_{2} \text { emisyonu, doğrudan sera gazı salınımı, dolaylı sera gazı salınımı }\end{array}$ \\
\hline Goyal vd. (2015) & $\begin{array}{c}\text { Kurumsal yönetim, pazar değeri, inovasyon, çalışan sorumluluğu, müşteri sorumluluğu, } \\
\text { çevre dostu ürünler, kirlilik kontrolü, çevre yönetimi }\end{array}$ \\
\hline Aras vd. (2016) & $\begin{array}{c}\text { Enerji tüketimi, enerji tasarrufu, sera gazı salınımı, su tüketimi, kağıt tüketimi, } \mathrm{CO}_{2} \text { emis- } \\
\text { yonu, eğitim, çalışan sayısı, çalışan devir hızı }\end{array}$ \\
\hline Rebai vd. (2016) & $\begin{array}{l}\mathrm{CO}_{2} \text { emisyonu, eğitim, ATM sayısı, özkaynak karlılığı, aktif karlılığı, şube sayısı, mevduat } \\
\text { faiz oranı, kredi faiz oranı, kadın temsil oranı, engelli çalışan sayısı }\end{array}$ \\
\hline Ömürbek vd. (2017) & $\begin{array}{c}\text { Toplam aktif değişim oranı, nakdi krediler değişim oranı, toplam özkaynak değişim oranı, } \\
\text { mevduat değişim oranı, sermaye yeterlilik oranı, şube sayısı, müşteri sayısı, ATM sayısı, } \\
\text { çalışan sayısı, çalışan başına ortalama eğitim süresi, kapsam } 1 \text { emisyonu, kapsam } 2 \text { emis- } \\
\text { yonu }\end{array}$ \\
\hline Aras vd. (2018) & $\begin{array}{l}\text { Sermaye yapısı, finansal büyüme, kredi portföyü, enerji tüketimi, enerji tasarrufu, enerji } \\
\text { verimliliği, geri dönüşüm için yapılan yatırımlar, sera gazı, su tüketimi, kağıt tüketimi, } \\
\qquad \mathrm{CO}_{2} \text { emisyonu, çalışan sayısı }\end{array}$ \\
\hline $\begin{array}{l}\text { Korzeb ve Sama- } \\
\text { niego-Medina } \\
\quad(2019)\end{array}$ & Maliyet/gelir, maliyet/aktifler, enerji tasarrufu, çevresel finansman, eğitim \\
\hline
\end{tabular}


Çalışmanın evrenini Türkiye'deki özel sermayeli bankalar oluşturmuştur. TBB'den alınan bilgilere göre ülkemizdeki özel sermayeli banka sayısı 9'dur. Ancak bunların dördü sürdürülebilirlik raporu yayımlamadığı için analizlere dahil edilememiştir. Böylece çalışmada Akbank, Şekerbank, TEB, Türkiye İş Bankası ve Yapı Kredi Bankası'nın kurumsal sürdürülebilirlik performansları incelenmiştir. Daha önce de belirtildiği gibi ekonomik veriler TBB'den, sosyal ve çevresel veriler ise bankaların en güncel sürdürülebilirlik raporlarından derlenmiştir. Performans ölçümünde yararlanılan veriler ise Tablo 2'de yer almaktadır. Öte yandan, Tablo 2'deki verilerden bazıları sürdürülebilirlik raporlarında hazır veri olarak bulunurken bazılarında birtakım hesaplamalar yapılarak gerekli veriler elde edilmiş ve analizlerde kullanılmıştır.

Şekil 1: Kurumsal Sürdürülebilirlik Performansının Değerlendirilmesi

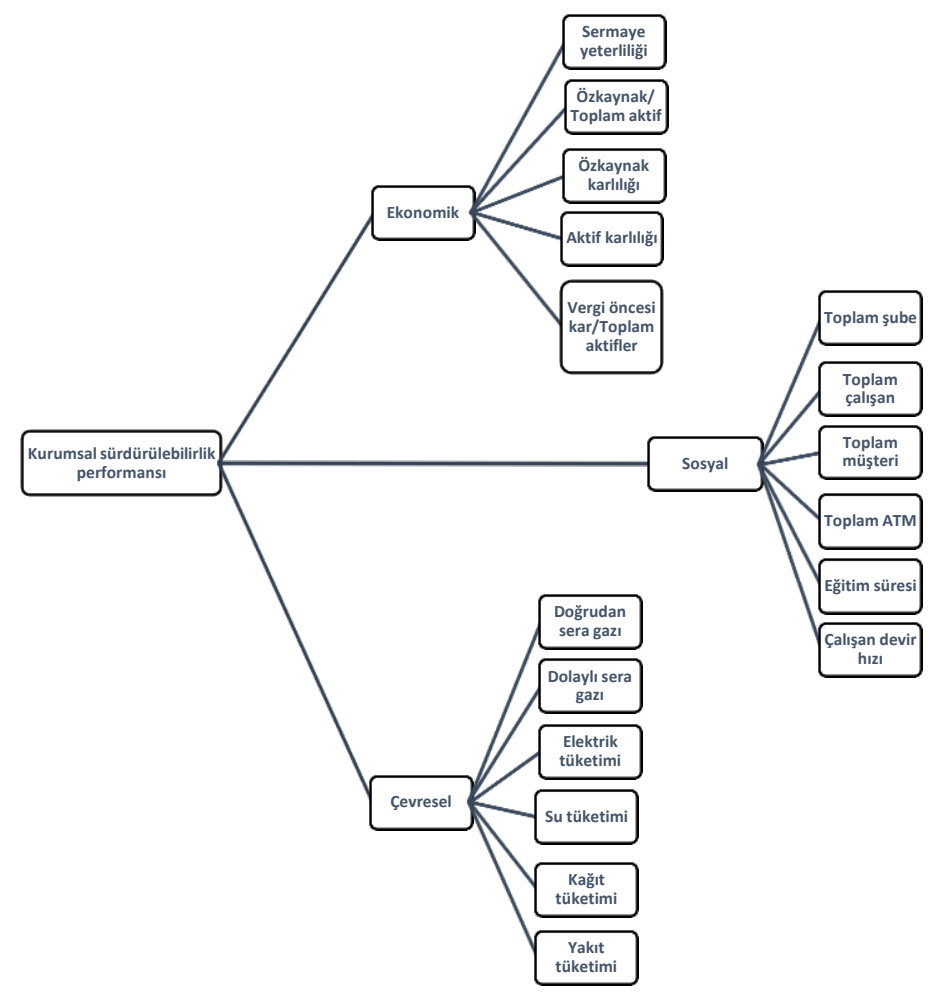


Ağustos 2019, C. 14, S. 2

Tablo 2: Analizlerde Kullanılan Veriler

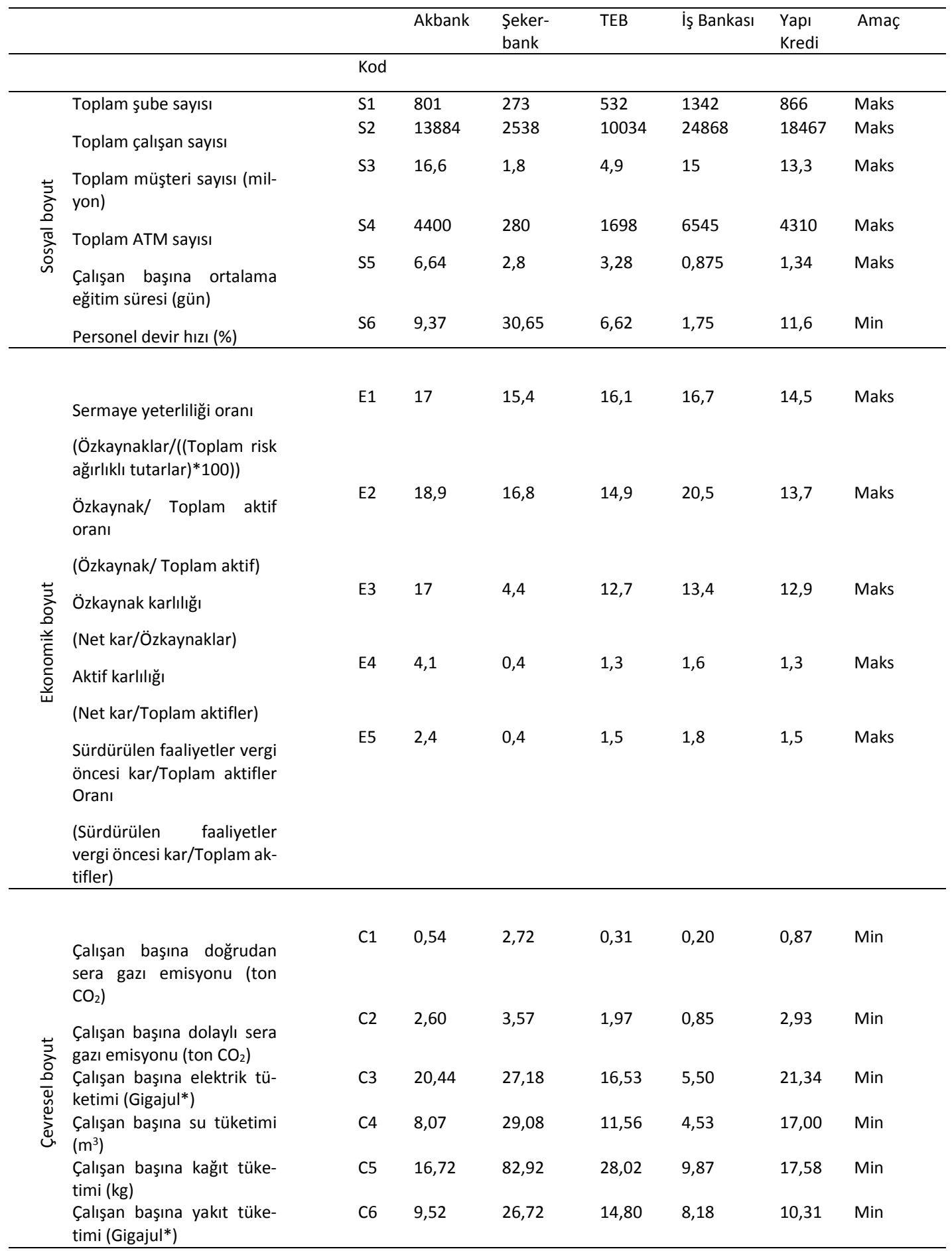

\footnotetext{
*1 gigajul=27778 kwh
} 
Şekil 2'de çalışmada bankaların kurumsal sürdürülebilirlik performansını ölçmek için önerilen modelin aşamaları verilmiştir. Şekil 2'ye göre öncelikle analizlerde kullanılacak göstergeler belirlenmiştir. Ardından entropi yöntemi ile bu göstergelerin önem ağırlıkları hesaplanmıştır. Son olarak hesaplanan önem ağırlıkları ARAS yönteminin algoritmasında kullanılarak bankalara ilişkin sürdürülebilirlik performans değerlerine ulaşılmıştır.

Şekil 2: Bankaların sürdürülebilirlik performanslarının ölçüm süreci

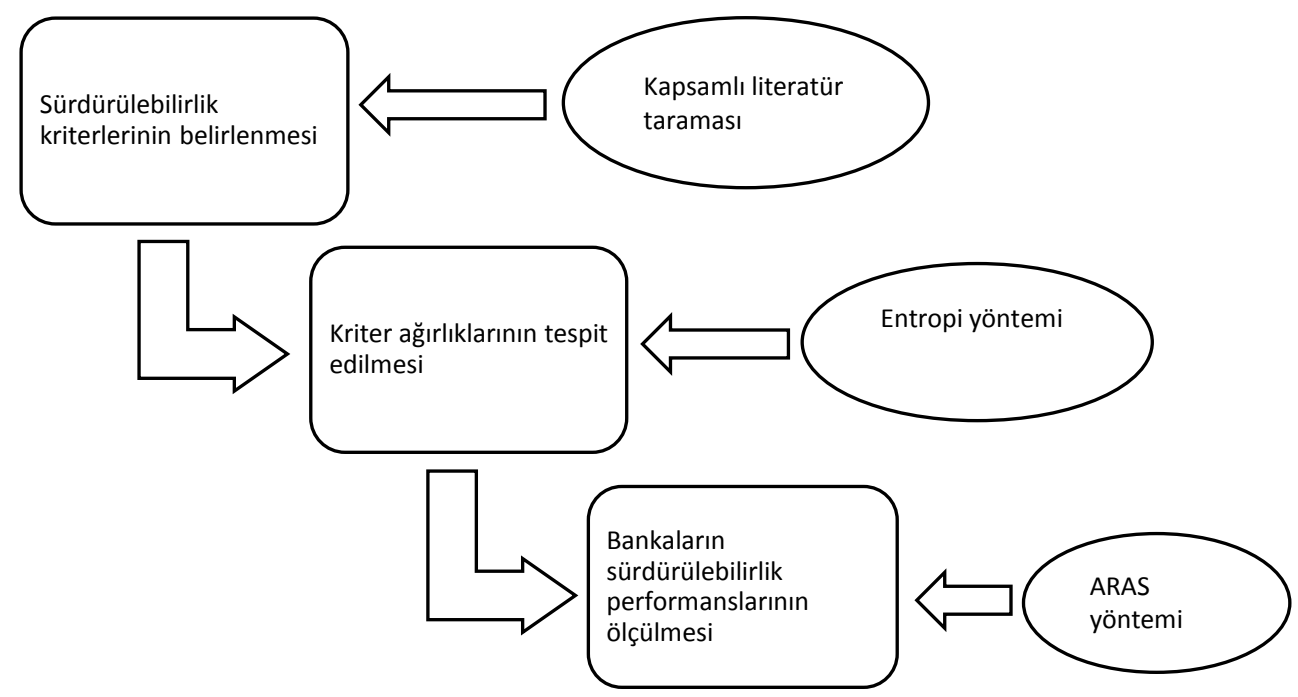

\subsection{Veri Seti}

2001 krizi sonrası yaşanan skandallar sonrası yapılan düzenlemeler bankaların hem bağımsız kuruluşlar tarafından denetlenmesini hem de kendi iç denetim mekanizmalarınca kontrolünü zorunlu kılmıştır. Bu nedenle ülkemizde bankalar Basel düzenlemeleri çerçevesinde kurumsal yönetim uygulamaların odak noktasına iç denetimi ve bağımsız kuruluşlarca yapılan denetimi yerleştirmişlerdir (Ceran, 2009). Ülkemizdeki bankalar, Bankacılık Düzenleme ve Denetim Kurulu (BDDK) tarafından yayınlanan yönetmeliklere uygun bir iç denetim mekanizması kurmak zorundadırlar. Buna ek olarak bankalar yeterli sayıda müfettişi denetim işinde görevlendirmek zorundadırlar. Bankaların dış denetimleri ise gerek BDDK adına yeminli murakıplarca gerekse de bağımsız dış denetim şirketleri tarafından gerçekleştirilmektedir. Bankalar, denetimler neticesinde onaylanan verileri ise hem BDDK hem de bankalar kurumsal raporlar aracılığıyla paylaşmaktadır. Bu nedenle bu çalışmada kullanılan veriler, denetim altında hazırlanan verilerden derlenmiştir.

Daha önce de vurgulandığı gibi bu çalışmada Türkiye'deki 5 özel sermayeli mevduat bankasının (Akbank, Şekerbank, TEB, Türkiye İş Bankası, Yapı Kredi Bankası) sürdürülebilirlik performansları değerlendirilmiştir. Sürdürülebilirlik performansları ölçülen bankalara ait bilgiler çalışmanın sonunda ekler bölümünde bulunabilir. Öte yandan bazı verilere doğrudan raporlardan ulaşılabilirken bazılarını elde etmek için birtakım hesaplamalar yapılmıştır. Örneğin sürdürülebilirlik raporlarında personel devir hızı verisi olmadığından bu veriyi elde etmek için önce işten ayrılan çalışan sayısına ulaşılmış, ardından bu veri toplam çalışan sayısına bölünerek bankaların personel devir hızı verisi elde edilmiştir. Benzer şekilde bankanın toplam kağıt tüketimi verisi, çalışan sayısına bölünerek çalışan başına kağıt tüketimi verisi elde edilmiştir. 


\subsection{Bulgular ve Değerlendirme}

Çalışmada öncelikle ekonomik, sosyal ve çevresel boyut altında yer alan 17 kriterin önem ağılıkları entropi yöntemiyle belirlenmiştir. Bu amaçla bankaların belirtilen kriterlere ilişkin verilerinin yer aldığı Tablo 2 kullanıımıştır. Entropi yöntemi kullanılarak elde edilen ağırlıklar Tablo 3'te gösterilmiştir.

Tablo 3: Kriterlerin Önem Ağırlıkları

\begin{tabular}{llllllll}
\hline & S1 & S2 & S3 & S4 & S5 & S6 & Toplam \\
$e_{j}$ & 0,9291 & 0,8948 & 0,8786 & 0,8439 & 0,8635 & 0,7317 & \\
$w_{j}$ & 0,0400 & 0,0594 & 0,0685 & 0,0881 & 0,0771 & 0,1515 & 0,485 \\
& & & & & & & \\
$e_{j}$ & E1 & E2 & E3 & E4 & E5 & & \\
$w_{j}$ & 0,0006 & 0,9933 & 0,9564 & 0,8547 & 0,9324 & & \multirow{2}{*}{0,149} \\
& & 0,0038 & 0,0246 & 0,0820 & 0,0382 & & \\
$e_{j}$ & 0,8389 & 0,9022 & 0,8691 & 0,8863 & 0,8967 & 0,9581 & \\
$w_{j}$ & 0,0909 & 0,0552 & 0,0739 & 0,0642 & 0,0583 & 0,0237 & 0,366 \\
\hline
\end{tabular}

Elde edilen bulgulara göre bankaların sürdürülebilirlik performanslarını değerlendirmede en önemli gösterge 0,151 ile personel devir hızı olmuştur. Onu sırasıyla 0,091 ile çalışan başına doğrudan sera gazı tüketimi, 0,088 ile toplam ATM sayısı ve 0,082 ile aktif karlılığı izlemiştir. Diğer taraftan en düşük önem ağırlığına sahip göstergeler ise 0,001 ile sermaye yeterlilik oranı, 0,004 ile özkaynaklar/toplam aktif oranı ve 0,024 ile çalışan başına yakıt tüketimi olmuştur. Sürdürülebilirlik performansı ölçümünde dikkate alınan boyutlar açısından ise sosyal boyutun $\% 48,5$ ile ilk sırada yer aldığı, onu \%36,6 ile çevresel boyutun izlediği ve son sırada ise ekonomik boyutun \%14,9 önem düzeyi ile yer aldığı görülmüştür.

17 göstergeye ait önem ağırlıklarının bulunmasının ardından analizin ikinci aşamasına geçilmiştir. Bu aşamada oldukça yeni bir yöntem olan ARAS yöntemi kullanılmıştır. ARAS yönteminde alternatiflerin yanında bir de optimal alternatif yer alır. Optimal alternatif, dikkate alınan veriler çerçevesinde \%100 performans gösteren kusursuz bir alternatif olarak düşünülebilir. ARAS yönteminde önce başlangıç karar matrisi oluşturulur. Bu matris analizdeki verilerin yer aldığı matris olup tek farkı optimal alternatifin de matriste yer almasıdır. Optimal alternatifin değerleri belirlenirken iki farklı yöntem izlenir. Yüksek olması daha iyi olan kriter için ilgili kritere göre alternatiflerin aldığı en yüksek değer seçilir. Aksine düşük olması daha iyi olan kriterler için ise ilgili kritere göre alternatiflerin aldığı en düşük değer dikkate alınır. Ayrıca, başlangıç matrisinde düşük olması daha iyi olan kriterlerin tersleri yer alır. Çalışmada oluşturulan başlangıç karar matrisi Tablo 4'te verilmiştir.

Başlangıç matrisinin oluşturulmasından sonra normalize karar matrisi elde edilir. Normalize karar matrisi, sütundaki her değerin o sütunun toplamına bölünmesi sonucunda elde edilen matristir ve Tablo 5'te verilmiştir. Sonraki aşamada, entropi yöntemiyle hesaplanan ağırlıklar analizlere dahil edilmiştir ve ağırlıklı normalize karar matrisi bulunmuştur (Tablo 6). 
Tablo 4: Başlangıç Matrisi

\begin{tabular}{|c|c|c|c|c|c|c|c|c|c|c|c|c|c|c|c|c|c|}
\hline & Kriterler & & & & & & & & & & & & & & & & \\
\hline $\begin{array}{l}\text { Optimi- } \\
\text { zasyon }\end{array}$ & $\begin{array}{l}\text { E1 } \\
\text { maks }\end{array}$ & $\begin{array}{l}E 2 \\
\text { maks }\end{array}$ & $\begin{array}{l}\text { E3 } \\
\text { maks }\end{array}$ & $\begin{array}{l}\text { E4 } \\
\text { maks }\end{array}$ & $\begin{array}{l}E 5 \\
\text { maks }\end{array}$ & $\begin{array}{l}\text { S1 } \\
\text { maks }\end{array}$ & $\begin{array}{l}S 2 \\
\text { maks }\end{array}$ & $\begin{array}{l}\text { S3 } \\
\text { maks }\end{array}$ & $\begin{array}{l}S 4 \\
\text { maks }\end{array}$ & $\begin{array}{l}S 5 \\
\text { maks }\end{array}$ & $\begin{array}{l}56 \\
\mathrm{~min}\end{array}$ & $\begin{array}{l}\mathrm{C1} \\
\mathrm{min}\end{array}$ & $\begin{array}{l}\mathrm{C2} \\
\mathrm{min}\end{array}$ & $\begin{array}{l}\mathrm{C3} \\
\mathrm{min}\end{array}$ & $\begin{array}{l}\text { C4 } \\
\text { min }\end{array}$ & $\begin{array}{l}\mathrm{C5} \\
\mathrm{min}\end{array}$ & $\begin{array}{l}\text { C6 } \\
\text { min }\end{array}$ \\
\hline Optimal & 17,0000 & 20,5000 & 17,0000 & 4,1000 & 2,4000 & 1342 & 24868 & 16,6000 & 6545 & 6,6400 & 0,5714 & 5,0000 & 1,1765 & 0,1818 & 0,2208 & 0,1013 & 0,1222 \\
\hline Akbank & 17,0000 & 18,9000 & 17,0000 & 4,1000 & 2,4000 & 801 & 13884 & 16,6000 & 4400 & 6,6400 & 0,1067 & 1,8519 & 0,3846 & 0,0489 & 0,1239 & 0,0598 & 0,1050 \\
\hline $\begin{array}{l}\text { Şeker- } \\
\text { bank }\end{array}$ & 15,4000 & 16,8000 & 4,4000 & 0,4000 & 0,4000 & 273 & 2538 & 1,8000 & 280 & 2,8000 & 0,0326 & 0,3676 & 0,2801 & 0,0368 & 0,0344 & 0,0121 & 0,0374 \\
\hline TEB & 16,1000 & 14,9000 & 12,7000 & 1,3000 & 1,5000 & 532 & 10034 & 4,9000 & 1698 & 3,2800 & 0,1511 & 3,2258 & 0,5076 & 0,0605 & 0,0865 & 0,0357 & 0,0676 \\
\hline $\begin{array}{l}\text { İş Ban- } \\
\text { kası }\end{array}$ & 16,7000 & 20,5000 & 13,4000 & 1,6000 & 1,8000 & 1342 & 24868 & 15,0000 & 6545 & 0,8750 & 0,5714 & 5,0000 & 1,1765 & 0,1818 & 0,2208 & 0,1013 & 0,1222 \\
\hline $\begin{array}{l}\text { Yapı } \\
\text { Kredi }\end{array}$ & 14,5000 & 13,7000 & 12,9000 & 1,3000 & 1,5000 & 866 & 18467 & 13,3000 & 4310 & 1,3400 & 0,0862 & 1,1494 & 0,3413 & 0,0469 & 0,0588 & 0,0569 & 0,0970 \\
\hline \multicolumn{18}{|c|}{ Tablo 5: Normalize Karar Matrisi } \\
\hline & Kriterler & & & & & & & & & & & & & & & & \\
\hline $\begin{array}{l}\text { Optimi- } \\
\text { zasyon }\end{array}$ & $\begin{array}{l}\text { E1 } \\
\text { maks }\end{array}$ & $\begin{array}{l}\text { E2 } \\
\text { maks }\end{array}$ & $\begin{array}{l}\text { E3 } \\
\text { maks }\end{array}$ & $\begin{array}{l}\text { E4 } \\
\text { maks }\end{array}$ & $\begin{array}{l}\text { E5 } \\
\text { maks }\end{array}$ & $\begin{array}{l}\text { S1 } \\
\text { maks }\end{array}$ & $\begin{array}{l}\text { S2 } \\
\text { maks }\end{array}$ & $\begin{array}{l}\text { S3 } \\
\text { maks }\end{array}$ & $\begin{array}{l}\text { S4 } \\
\text { maks }\end{array}$ & $\begin{array}{l}\text { S5 } \\
\text { maks }\end{array}$ & $\begin{array}{l}56 \\
\min \end{array}$ & $\begin{array}{l}C 1 \\
\min \end{array}$ & $\begin{array}{l}C 2 \\
\min \end{array}$ & $\begin{array}{l}\text { C3 } \\
\min \end{array}$ & $\begin{array}{l}\text { C4 } \\
\min \end{array}$ & $\begin{array}{l}\text { C5 } \\
\min \end{array}$ & $\begin{array}{l}\text { C6 } \\
\min \end{array}$ \\
\hline Optimal & 0,1758 & 0,1947 & 0,2196 & 0,3203 & 0,2400 & 0,2603 & 0,2627 & 0,2434 & 0,2753 & 0,3078 & 0,3761 & 0,3013 & 0,3043 & 0,3266 & 0,2963 & 0,2760 & 0,2217 \\
\hline Akbank & 0,1758 & 0,1795 & 0,2196 & 0,3203 & 0,2400 & 0,1554 & 0,1467 & 0,2434 & 0,1850 & 0,3078 & 0,0702 & 0,1116 & 0,0995 & 0,0879 & 0,1663 & 0,1629 & 0,1905 \\
\hline $\begin{array}{l}\text { Şeker- } \\
\text { bank }\end{array}$ & 0,1593 & 0,1595 & 0,0568 & 0,0313 & 0,0400 & 0,0529 & 0,0268 & 0,0264 & 0,0118 & 0,1298 & 0,0215 & 0,0222 & 0,0724 & 0,0661 & 0,0461 & 0,0329 & 0,0679 \\
\hline TEB & 0,1665 & 0,1415 & 0,1641 & 0,1016 & 0,1500 & 0,1032 & 0,1060 & 0,0718 & 0,0714 & 0,1520 & 0,0994 & 0,1944 & 0,1313 & 0,1087 & 0,1161 & 0,0972 & 0,1225 \\
\hline $\begin{array}{l}\text { İş Ban- } \\
\text { kası }\end{array}$ & 0,1727 & 0,1947 & 0,1731 & 0,1250 & 0,1800 & 0,2603 & 0,2627 & 0,2199 & 0,2753 & 0,0406 & 0,3761 & 0,3013 & 0,3043 & 0,3266 & 0,2963 & 0,2760 & 0,2217 \\
\hline $\begin{array}{l}\text { Yapı } \\
\text { Kredi }\end{array}$ & 0,1499 & 0,1301 & 0,1667 & 0,1016 & 0,1500 & 0,1680 & 0,1951 & 0,1950 & 0,1813 & 0,0621 & 0,0567 & 0,0693 & 0,0883 & 0,0842 & 0,0789 & 0,1550 & 0,1759 \\
\hline
\end{tabular}

Tablo 6: Ağırlıklı Normalize Karar Matrisi

\begin{tabular}{|c|c|c|c|c|c|c|c|c|c|c|c|c|c|c|c|c|c|}
\hline & $\begin{array}{l}\text { Kriter- } \\
\text { ler }\end{array}$ & & & & & & & & & & & & & & & & \\
\hline & $E 1$ & $E 2$ & $E 3$ & $E 4$ & E5 & s1 & s2 & 53 & 54 & 55 & 56 & C1 & $C 2$ & C3 & C4 & $C 5$ & C6 \\
\hline $\begin{array}{l}\text { Önem } \\
\text { ağırlıkları }\end{array}$ & 0,0006 & 0,0038 & 0,0246 & 0,0820 & 0,0382 & 0,0400 & 0,0594 & 0,0685 & 0,0881 & 0,0771 & 0,1515 & 0,0909 & 0,0552 & 0,0739 & 0,0642 & 0,0583 & 0,0237 \\
\hline Optimal & 0,0001 & 0,0007 & 0,0054 & 0,0263 & 0,0092 & 0,0104 & 0,0156 & 0,0167 & 0,0243 & 0,0237 & 0,0570 & 0,0274 & 0,0168 & 0,0241 & 0,0190 & 0,0161 & 0,0052 \\
\hline Akbank & 0,0001 & 0,0007 & 0,0054 & 0,0263 & 0,0092 & 0,0062 & 0,0087 & 0,0167 & 0,0163 & 0,0237 & 0,0106 & 0,0101 & 0,0055 & 0,0065 & 0,0107 & 0,0095 & 0,0045 \\
\hline Şekerbank & 0,0001 & 0,0006 & 0,0014 & 0,0026 & 0,0015 & 0,0021 & 0,0016 & 0,0018 & 0,0010 & 0,0100 & 0,0033 & 0,0020 & 0,0040 & 0,0049 & 0,0030 & 0,0019 & 0,0016 \\
\hline TEB & 0,0001 & 0,0005 & 0,0040 & 0,0083 & 0,0057 & 0,0041 & 0,0063 & 0,0049 & 0,0063 & 0,0117 & 0,0151 & 0,0177 & 0,0073 & 0,0080 & 0,0075 & 0,0057 & 0,0029 \\
\hline Yapı Kredi & 0,0001 & 0,0005 & 0,0041 & 0,0083 & 0,0057 & 0,0067 & 0,0116 & 0,0134 & 0,0160 & 0,0048 & 0,0086 & 0,0063 & 0,0049 & 0,0062 & 0,0051 & 0,0090 & 0,0042 \\
\hline
\end{tabular}


En son aşamada ise optimallik fonksiyonu değeri $S$ ile fayda derecesi $K$ hesaplanmıştır. $S$ değerinin hesaplanmasında (13), $K$ değerinin hesaplanmasında ise (14) numaralı formüller kullanılmıştır. $S$ ve $K$ değerleri Tablo 7'deki gibidir. Bu çalışmada sürdürülebilirlik performansı anlamına gelmekte olan $K$ değerlerine göre ise bankalar en iyiden en kötüye doğru sıralanmıştır. Elde edilen sonuçlara göre en iyi kurumsal sürdürülebilirlik performansı sergileyen banka Şekil 3'te de görüldüğü gibi \%86,02 ile Türkiye İş Bankası'dır. Türkiye İş Bankası'nı \% 57,28 ile Akbank izlemektedir. TEB ile Yapı Kredi Bankası'nın sürdürülebilirlik performansı birbirine oldukça yakın bulunmuştur ve sırasıyla \% 38,97 ve \% 38,73’tür. Son sırada ise \% 14,56 ile Şekerbank yer almıştır.

Tablo 7: Bankaların Kurumsal Sürdürülebilirlik Performanslarına Göre Sıralamaları

\begin{tabular}{llll}
\hline & $S$ & $K$ (Performans puanı) & Sıralama \\
\hline Optimal & 0,2980 & 1,0000 & Optimal \\
Akbank & 0,1707 & 0,5728 & 2. \\
Şekerbank & 0,0434 & 0,1456 & 5. \\
TEB & 0,1161 & 0,3897 & 3. \\
İ̧̧ Bankası & 0,2564 & 0,8602 & 1. \\
Yapı Kredi & 0,1154 & 0,3873 & 4. \\
\hline
\end{tabular}

Şekil 3: Bankaların Kurumsal Sürdürülebilirlik Performansları

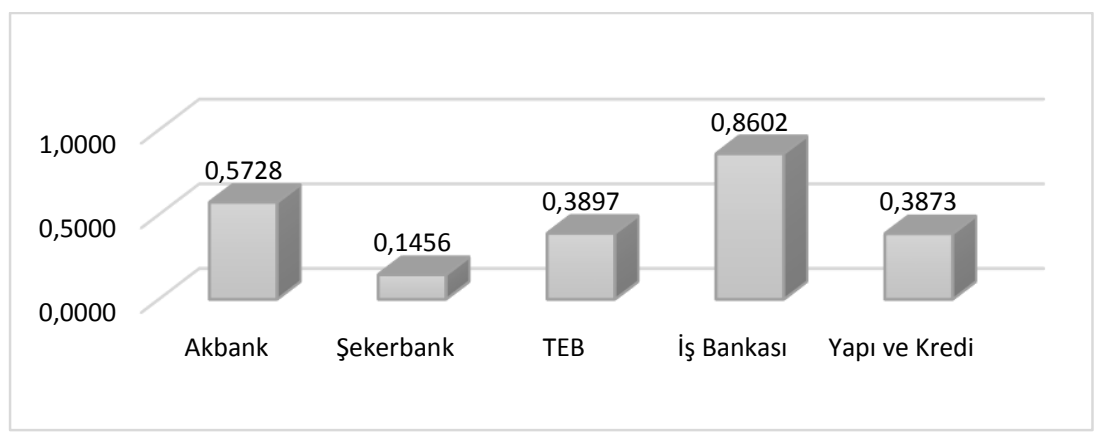

Entropi-ARAS bütünleşik modeli kullanılarak yapılan sürdürülebilirlik performansına göre ilk sırada Türkiye İş Bankası yer almıştır ve yaklaşık \% 86'lık bir performans değerine ulaşmıştır. Bulgulara göre Türkiye İş Bankası, 17 göstergenin 11'inde en iyi konumdadır ve bunun sonucunda genel değerlendirmede de ilk sıradadır. Ayrıca en iyi olduğu 11 göstergenin 10'u da sosyal ve çevresel boyuta ilişkin göstergelerdedir ve bunun doğal sonucu olarak Türkiye İş Bankası sürdürülebilirlik açısından en yüksek performans değerine ulaşan banka olmuştur. Analizler sonucunda Türkiye İş Bankası'nın çevresel boyutta yer alan tüm göstergeler bakımından tüm bankalar arasında en iyi durumda olduğu görülmüştür. Elde edilen sonuçlara göre Türkiye İş Bankası'nın doğaya saygılı bir banka olduğu ve çevreci bir anlayışla yönetildiği söylenebilir. Banka, sosyal göstergelerden toplam şube sayısı, toplam çalışan sayısı, toplam ATM sayısı ve çalışan devir hızı bakımından yine en iyi bankadır. Tüm bunlara karşın, bankanın ekonomik göstergelerden sadece özkaynaklar/toplam aktif oranı göstergesinde en iyi olduğu görülmüştür. Bulgular çerçevesinde bankanın ekonomik göstergelerini düzeltecek yönde adımlar atması sürdürülebilirlik performansının daha yüksek seviyelere ulaşmasını sağlayacaktır. 
Genel değerlendirmede ikinci sırada Akbank yer almıştır. Akbank, değerlendirmede yer alan 6 göstergeye göre rakiplerinin önünde yer almıştır. Bunlar ekonomik boyuta ilişkin göstergelerden sermaye yeterliliği oranı, özkaynak karlılı̆̆ı, aktif karlılı̆ı, sürdürülen faaliyetler vergi öncesi kar/toplam aktifler oranı ile sosyal boyutta yer alan toplam müşteri sayısı ve çalışan başına düşen ortalama eğitim süresidir. Çalışmanın sonuçlarına göre Akbank'ın daha çok finansal boyuta önem verdiği, çevresel ve sosyal boyutu biraz göz ardı ettiği görülmektedir. Sonuç olarak Akbank, yaklaşık \%57'lik sürdürülebilirlik performansını ancak çevresel ve sosyal boyuta da ekonomik boyut kadar önem verirse arttırma şansına sahiptir.

TEB ile Yapı Kredi Bankası, Akbank'ın ardından birbirine oldukça yakın performans göstererek sırasıyla üçüncü ve dördüncü sıralarda yer almışlardır. Yaklaşık \% 39'luk performans ne TEB ne de Yapı Kredi Bankası gibi Türkiye'nin önde gelen bankaları için yeterli görülebilecek bir performanstır. Elde edilen bulgulara göre TEB, ekonomik boyutta önündeki rakiplere nispeten yakın görünse de çevresel ve sosyal boyutlar açısından iyi performansa sahip değildir. Çalışmada iyi bir sürdürülebilirlik performansı göstermemiş olan Yapı Kredi Bankası'nda personel devir hızının yüksek olması bunun nedenlerinden biri olarak dikkat çekmektedir.

Son olarak Şekerbank, analiz sonuçlarına göre yaklaşık \%14'lük sürdürülebilirlik performans değeri ile son sırada yer almıştır. Banka, özellikle çevreye duyarlı olmayan özellikleriyle dikkat çekmektedir. Toplam çalışan sayısı analizde yer alan bankalar arasında en az olan banka olmasına rağmen bankanın personel devir hızı en yüksek banka olması dikkat çekicidir.

\subsection{Duyarlılık Analizi}

Çalışmada, kriterlerin önem ağırlıkları değiştirildiğinde, bankaların kurumsal sürdürülebilirlik performanslarına ilişkin sıralamanın nasıl etkilendiğini belirlemek için bir duyarlılık analizi uygulanmıştır. Bu bağlamda, entropi yöntemiyle bulunan öncelik ağırlıklarından iki tanesi, diğerleri sabit tutulmak şartıyla birbirleriyle yer değiştirilmiştir. Örneğin, sermaye yeterliliği oranının $\left(E_{1}\right)$ öncelik ağırlı̆̆ı diğerleri sabitken, sırasıyla özkaynak/toplam aktif oranının $\left(E_{2}\right)$, özkaynak karlılığının $\left(E_{3}\right), \ldots$, çalışan başına yakıt tüketiminin $\left(C_{6}\right)$ öncelik ağırlığı ile değiştirilmiştir. Daha sonra bankaları sıralamak için ARAS yöntemi tekrar uygulanmıştır. Böylece, önerilen modelin önem ağırlığı değişimlerine karşı kararlılığı ve davranışı gözlemlenmiştir. Bu süreçte on altı tane karşılıklı ağırlık değişimi gerçekleştirilmiştir. Tablo 8'de farklı senaryolar neticesinde ortaya çıkan performans sonuçları gösterilmiştir. Ayrıca, Tablo 8'deki sonuçlar analiz edilmiş ve Şekil 4'te gösterilmiştir.

Duyarlılık analizinde ele alınan farklı senaryolardan birkaç tanesinin sonucu dikkat çekicidir. Örneğin Senaryo 9'da sermaye yeterliliği oranı (E1) ile çalışan başına ortalama eğitim süresinin (S5) önem ağılıkları değiştirildiğinde Türkiye İş Bankası'nın performansı yükselirken diğer tüm bankaların performansları düşmüştür. Ayrıca Türkiye İ̧ Bankası'nın performansı tüm senaryolar içerisindeki en yüksek performans değerine $(0,9255)$ ulaşmıştır. Senaryo 10 'da ise personel devir hızı (S6) ile sermaye yeterliliği oranının (E1) önem ağılıklarının yer değiştirmesiyle Türkiye İş Bankası'nın performansı düşerken diğer bankaların performansları yükselmiştir. Burada, Türkiye İş Bankası'nın performansı dikkate alınan 16 farklı senaryodaki en düşük performans değerine düşerken Şekerbank'ın performansı ise en iyi performans değerine $(0,2397)$ ulaşmıştır. 
Ağustos 2019, C. 14, S. 2

Tablo 8: Duyarlılık Analizi Sonuçları

\begin{tabular}{|c|c|c|c|c|c|c|c|c|c|c|c|c|c|c|c|c|c|c|}
\hline \multirow[b]{2}{*}{ 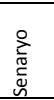 } & \multirow[b]{2}{*}{ 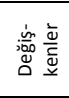 } & \multicolumn{17}{|c|}{ Kurumsal sürdürülebilirlik kriterleri } \\
\hline & & E1 & E2 & E3 & E4 & E5 & $\mathrm{s} 1$ & S2 & s3 & S4 & S5 & s6 & $\mathrm{C} 1$ & $\mathrm{C} 2$ & C3 & $\mathrm{C} 4$ & C5 & C6 \\
\hline \multirow[t]{2}{*}{$M D^{*}$} & $\mathrm{w}_{1}$ & 0,0006 & 0,0038 & 0,0246 & 0,0820 & 0,0382 & 0,0400 & 0,0594 & 0,0685 & 0,0881 & 0,0771 & 0,1515 & 0,0909 & 0,0552 & 0,0739 & 0,0642 & 0,0583 & 0,0237 \\
\hline & $\begin{array}{l}\text { Sira- } \\
\text { lama }\end{array}$ & \multicolumn{17}{|c|}{ iss bankası $(0,8602) \succ$ Akbank $(0,5728) \succ$ TEB $(0,3897) \succ$ Yapı Kredi $(0,3873) \succ$ şekerbank $(0,1456)$} \\
\hline \multirow[t]{2}{*}{1} & $w_{2}$ & 0,0038 & 0,0006 & 0,0246 & 0,0820 & 0,0382 & 0,0400 & 0,0594 & 0,0685 & 0,0881 & 0,0771 & 0,1515 & 0,0909 & 0,0552 & 0,0739 & 0,0642 & 0,0583 & 0,0237 \\
\hline & $\begin{array}{l}\text { Sira- } \\
\text { lama }\end{array}$ & \multicolumn{17}{|c|}{ Iş bankası $(0,8602) \succ$ Akbank $(0,5729) \succ$ TEB $(0,3900) \succ_{\text {Yapı Kredi }(0,3876)} \succ_{\text {Şekerbank }(0,1456)}$} \\
\hline \multirow[t]{2}{*}{2} & $\mathrm{w}_{3}$ & 0,0246 & 0,0038 & 0,0006 & 0,0820 & 0,0382 & 0,0400 & 0,0594 & 0,0685 & 0,0881 & 0,0771 & 0,1515 & 0,0909 & 0,0552 & 0,0739 & 0,0642 & 0,0583 & 0,0237 \\
\hline & $\begin{array}{l}\text { Sira- } \\
\text { lama }\end{array}$ & \multicolumn{17}{|c|}{ iş bankası $(0,8632) \succ$ Akbank $(0,5713) \succ$ TEB $(0,3912) \succ$ Yapı Kredi $(0,3873) \succ$ şekerbank $(0,1544)$} \\
\hline \multirow[t]{2}{*}{3} & $\mathrm{w}_{4}$ & 0,0820 & 0,0038 & 0,0246 & 0,0006 & 0,0382 & 0,0400 & 0,0594 & 0,0685 & 0,0881 & 0,0771 & 0,1515 & 0,0909 & 0,0552 & 0,0739 & 0,0642 & 0,0583 & 0,0237 \\
\hline & $\begin{array}{l}\text { Sira- } \\
\text { lama }\end{array}$ & \multicolumn{17}{|c|}{ iş bankası $(0,9091) \succ$ Akbank $(0,5553) \succ$ TEB $(0,4241) \succ$ Yapı Kredi $(0,4170) \succ$ Şekerbank $(0,1880)$} \\
\hline \multirow[t]{2}{*}{4} & $w_{5}$ & 0,0382 & 0,0038 & 0,0246 & 0,0820 & 0,0006 & 0,0400 & 0,0594 & 0,0685 & 0,0881 & 0,0771 & 0,1515 & 0,0909 & 0,0552 & 0,0739 & 0,0642 & 0,0583 & 0,0237 \\
\hline & $\begin{array}{l}\text { Sira- } \\
\text { lama }\end{array}$ & \multicolumn{17}{|c|}{ iş bankası $(0,8663) \succ$ Akbank $(0,5694) \succ$ TEB $(0,3949) \succ$ Yapı Kredi $(0,3905) \succ$ Şekerbank $(0,1620)$} \\
\hline \multirow[t]{2}{*}{5} & $\mathrm{w}_{6}$ & 0,0400 & 0,0038 & 0,0246 & 0,0820 & 0,0382 & 0,0006 & 0,0594 & 0,0685 & 0,0881 & 0,0771 & 0,1515 & 0,0909 & 0,0552 & 0,0739 & 0,0642 & 0,0583 & 0,0237 \\
\hline & $\begin{array}{l}\text { Sira- } \\
\text { lama }\end{array}$ & \multicolumn{17}{|c|}{ Iş bankası $(0,8582) \succ$ Akbank $(0,5821) \succ$ TEB $(0,4025) \succ$ Yapı Kredi $(0,3893) \succ$ Şekerbank $(0,1615)$} \\
\hline \multirow[t]{2}{*}{6} & $\mathrm{w}_{7}$ & 0,0594 & 0,0038 & 0,0246 & 0,0820 & 0,0382 & 0,0400 & 0,0006 & 0,0685 & 0,0881 & 0,0771 & 0,1515 & 0,0909 & 0,0552 & 0,0739 & 0,0642 & 0,0583 & 0,0237 \\
\hline & $\begin{array}{l}\text { Sira- } \\
\text { lama }\end{array}$ & \multicolumn{17}{|c|}{ iş bankası $(0,8571) \succ$ Akbank $(0,5887) \succ_{\text {TEB }(0,4086)} \succ_{\text {Yapı Kredi }(0,3850)} \succ_{\text {Şekerbank }(0,1747)}$} \\
\hline \multirow[t]{2}{*}{7} & $\mathrm{w}_{8}$ & 0,0685 & 0,0038 & 0,0246 & 0,0820 & 0,0382 & 0,0400 & 0,0594 & 0,0006 & 0,0881 & 0,0771 & 0,1515 & 0,0909 & 0,0552 & 0,0739 & 0,0642 & 0,0583 & 0,0237 \\
\hline & $\begin{array}{l}\text { Sira- } \\
\text { lama }\end{array}$ & \multicolumn{17}{|c|}{ iş bankası $(0,8627) \succ$ Akbank $(0,5662) \succ$ TEB $(0,4177) \succ$ Yapı Kredi $(0,3829) \succ$ Şekerbank $(0,1786)$} \\
\hline \multirow[t]{2}{*}{8} & w9 & 0,0881 & 0,0038 & 0,0246 & 0,0820 & 0,0382 & 0,0400 & 0,0594 & 0,0685 & 0,0006 & 0,0771 & 0,1515 & 0,0909 & 0,0552 & 0,0739 & 0,0642 & 0,0583 & 0,0237 \\
\hline & $\begin{array}{l}\text { Sira- } \\
\text { lama }\end{array}$ & \multicolumn{17}{|c|}{ iş bankası $(0,8551) \succ$ Akbank $(0,5873) \succ$ TEB $(0,4301) \succ$ Yapı Kredi $(0,3895) \succ$ şekerbank $(0,1946)$} \\
\hline \multirow[t]{2}{*}{9} & $\mathrm{w}_{10}$ & 0,0771 & 0,0038 & 0,0246 & 0,0820 & 0,0382 & 0,0400 & 0,0594 & 0,0685 & 0,0881 & 0,0006 & 0,1515 & 0,0909 & 0,0552 & 0,0739 & 0,0642 & 0,0583 & 0,0237 \\
\hline & $\begin{array}{l}\text { Sira- } \\
\text { lama }\end{array}$ & \multicolumn{17}{|c|}{ iş bankası $(0,9255) \succ$ Akbank $(0,5579) \succ$ Yapı Kredi $(0,4242) \succ$ TEB $(0,4072) \succ$ Şekerbank $(0,1585)$} \\
\hline \multirow[t]{2}{*}{10} & $\mathrm{w}_{11}$ & 0,1515 & 0,0038 & 0,0246 & 0,0820 & 0,0382 & 0,0400 & 0,0594 & 0,0685 & 0,0881 & 0,0771 & 0,0006 & 0,0909 & 0,0552 & 0,0739 & 0,0642 & 0,0583 & 0,0237 \\
\hline & $\begin{array}{l}\text { Sira- } \\
\text { lama }\end{array}$ & \multicolumn{17}{|c|}{ iş bankası $(0,8427) \succ$ Akbank $(0,6970) \succ$ Yapı Kredi $(0,4835) \succ \operatorname{TEB}(0,4714) \succ$ şekerbank $(0,2397)$} \\
\hline \multirow[t]{2}{*}{11} & $\mathrm{w}_{12}$ & 0,0909 & 0,0038 & 0,0246 & 0,0820 & 0,0382 & 0,0400 & 0,0594 & 0,0685 & 0,0881 & 0,0771 & 0,1515 & 0,0006 & 0,0552 & 0,0739 & 0,0642 & 0,0583 & 0,0237 \\
\hline & $\begin{array}{l}\text { Sira- } \\
\text { lama }\end{array}$ & & & & & iş ban & ISI $(0,8537)$ & Akbank & 6157) $\succ$ & pI Kredi (0 & 280) $\succ \mathrm{TE}$ & $(0,3963)$ & S Şekerbank & ,1945) & & & & \\
\hline 12 & $\mathrm{w}_{13}$ & 0,0552 & 0,0038 & 0,0246 & 0,0820 & 0,0382 & 0,0400 & 0,0594 & 0,0685 & 0,0881 & 0,0771 & 0,1515 & 0,0909 & 0,0006 & 0,0739 & 0,0642 & 0,0583 & 0,0237 \\
\hline & $\begin{array}{l}\text { Sira- } \\
\text { lama }\end{array}$ & & & & & Iş ban & ISI $(0,8562$ & Akbank & $6010) \succ$ & pı Kredi (0 & 082) $\succ T$ & $(0,4057)\}$ & - Şekerbank & ,1654) & & & & \\
\hline
\end{tabular}


Eskişehir Osmangazi Üniversitesi IiBF Dergisi

\begin{tabular}{|c|c|c|c|c|c|c|c|c|c|c|c|c|c|c|c|c|c|c|}
\hline \multirow[t]{2}{*}{13} & $\mathrm{w}_{14}$ & 0,0739 & 0,0038 & 0,0246 & 0,0820 & 0,0382 & 0,0400 & 0,0594 & 0,0685 & 0,0881 & 0,0771 & 0,1515 & 0,0909 & 0,0552 & 0,0006 & 0,0642 & 0,0583 & 0,0237 \\
\hline & $\begin{array}{l}\text { Sira- } \\
\text { lama }\end{array}$ & \multicolumn{17}{|c|}{ Iş bankası $(0,8540) \succ_{\text {Akbank }(0,6174)} \succ_{\text {TEB }(0,4194)} \succ_{\text {Yapı Kredi }(0,4190)} \succ_{\text {Şekerbank }(0,1750)}$} \\
\hline \multirow[t]{2}{*}{14} & $\mathrm{w}_{15}$ & 0,0642 & 0,0038 & 0,0246 & 0,0820 & 0,0382 & 0,0400 & 0,0594 & 0,0685 & 0,0881 & 0,0771 & 0,1515 & 0,0909 & 0,0552 & 0,0739 & 0,0006 & 0,0583 & 0,0237 \\
\hline & $\begin{array}{l}\text { Sira- } \\
\text { lama }\end{array}$ & \multicolumn{17}{|c|}{ iş bankası $(0,8558) \succ$ Akbank $(0,5900) \succ$ Yapı Kredi $(0,4131) \succ$ TEB $(0,4110) \succ$ şekerbank $(0,1742)$} \\
\hline \multirow[t]{2}{*}{15} & $\mathrm{w}_{16}$ & 0,0583 & 0,0038 & 0,0246 & 0,0820 & 0,0382 & 0,0400 & 0,0594 & 0,0685 & 0,0881 & 0,0771 & 0,1515 & 0,0909 & 0,0552 & 0,0739 & 0,0642 & 0,0006 & 0,0237 \\
\hline & $\begin{array}{l}\text { Sira- } \\
\text { lama }\end{array}$ & \multicolumn{17}{|c|}{ iş bankası $(0,8568) \succ$ Akbank $(0,5867) \succ$ TEB $(0,4111) \succ$ Yapı Kredi $(0,3940) \succ$ şekerbank $(0,1734)$} \\
\hline \multirow[t]{2}{*}{16} & $\mathrm{w}_{17}$ & 0,0237 & 0,0038 & 0,0246 & 0,0820 & 0,0382 & 0,0400 & 0,0594 & 0,0685 & 0,0881 & 0,0771 & 0,1515 & 0,0909 & 0,0552 & 0,0739 & 0,0642 & 0,0583 & 0,0006 \\
\hline & $\begin{array}{l}\text { Sira- } \\
\text { lama }\end{array}$ & \multicolumn{17}{|c|}{ Iş bankası $(0,8595) \succ$ Akbank $(0,5738) \succ$ TEB $(0,3945) \succ$ Yapı Kredi $(0,3867) \succ$ şekerbank $(0,1532)$} \\
\hline
\end{tabular}

Not: Performans sonuçları parantez içinde verilmiştir. $\succ$ sembolü üstünlük anlamında kullanılmıştır. * Mevcut durum. 
Şekil 4'e göre Türkiye İş Bankası'nın gerek mevcut durumda, gerekse de önem ağırlıklarının değiştirilmesiyle gerçekleştirilen varsayımsal senaryolarda en iyi performansı gösteren banka olduğu görülmektedir. Türkiye İş Bankası'nın performansı \% 84,27 ile \% 92,55 arasında değişim göstermiştir. Akbank tüm senaryolarda yine en iyi ikinci banka olmuştur. Gerçek değerlendirmede birbirine çok yakın performans gösteren TEB ile Yapı Kredi Bankası, Tablo 8' de görüldüğü gibi duyarlılık analizinde de birbirine yakın değerler almıştır. Duyarlılık analizine göre son sırada ise yine Şekerbank yer almıştır. Böylece, duyarlılık analizine göre kriterlerin önem ağırlıkları değişse de bankaların sıralamalarının genellikle aynı olması önerilen modelin güçlü ve sağlam bir model olduğunu göstermektedir.

\section{Şekil 4: Farklı Önem Ağırlıklarına Göre Banka Performansları}

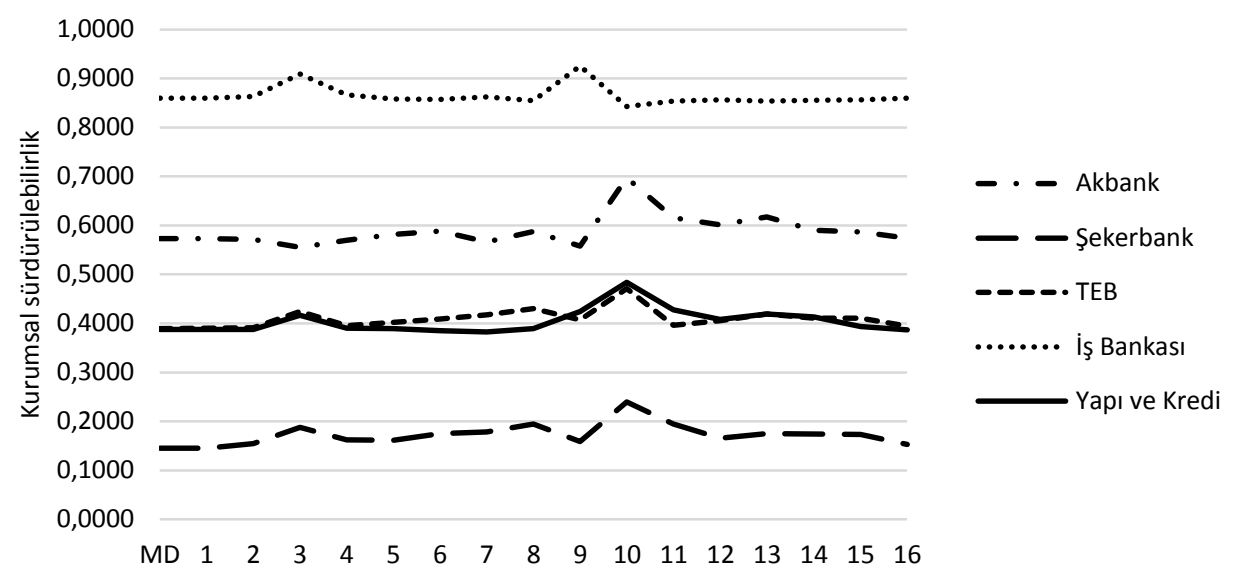

\section{Sonuç}

Günümüzde yatırımcılar açısından şirketlerin ekonomik performansları artık yatırım yapmada tek kriter değildir, şirketlerin sosyal ve çevresel performansları da dikkate alınan temel kriterler arasındadır. Ekonomik, sosyal ve çevresel boyutların bir araya gelmesiyle oluşan kurumsal sürdürülebilirlik performansının belirlenmesi bu nedenle kritik öneme sahiptir.

Bankaların kurumsal sürdürülebilirlik performanslarını ölçmek, pek çok kriter ve alternatifin karar sürecinde yer alması nedeniyle zor ve karmaşık bir ÇKKV problemidir. Çalışmada, bu sorunun çözümüne yönelik olarak entropi temelli ARAS yöntemi önerilmiştir. Bu bağlamda Türkiye'deki özel sermayeli 5 bankanın kurumsal sürdürülebilirlik performansı ekonomik, sosyal ve çevresel boyut kapsamında yer alan 17 göstergeye göre belirlenmiştir. Her göstergenin farklı önem düzeyinin olabileceğinden hareketle öncelikle 17 göstergenin önem ağırlıkları objektif ağırlıklandırma yöntemlerinden biri olan entropi yöntemiyle hesaplanmıştır. Ardından yeni bir ÇKKV yöntemi olan ve finans alanında henüz yok denecek kadar az uygulama alanı bulmuş olan ARAS yöntemi ile bankaların kurumsal sürdürülebilirlik performansı elde edilmiştir.

Çalışmanın bulgularına göre bankaların kurumsal sürdürülebilir performansının belirlenmesinde en önemli boyut sosyal boyuttur. Sosyal boyutta yer alan "personel devir hızı", "toplam ATM sayısı" ve "çalışan başına ortalama eğitim süresi" en yüksek ağırlığa sahip göstergelerdir. Bulgulara göre, çevresel boyut yaklaşık \% 37'lik oran ile sürdürülebilirlik üzerinde etkili olan bir boyuttur. Çevresel boyut kapsamında yer alan "çalışan başına doğrudan sera gazı emisyonu", "çalışan başına elektrik tüketimi" ve "çalışan başına su tüketimi" en önemli göstergelerdir. Son 
olarak ekonomik boyutta ise "aktif karlılığı", "sürdürülen faaliyetler vergi öncesi kar/toplam aktifler oranı" ve "özkaynak karlılığı" en önemli göstergeler olmuştur. Ancak ekonomik boyut, önem sıralamasında diğer iki boyutun gerisinde yer almıştır. Entropi ARAS bütünleşik modeli, Türkiye iş̧ Bankası'nın en iyi kurumsal sürdürülebilirlik performansına sahip özel sermayeli banka olduğunu göstermiştir. Türkiye İş Bankası'nın ardından ise sırasıyla Akbank, TEB, Yapı Kredi Bankası ve Şekerbank gelmiştir. Önerilen modelin etkinliğini ve sağlamlığını ortaya koymak için duyarlıık analizi de yapılmıştır.

Türkiye'de maalesef tüm bankalar sürdürülebilirlik raporu yayımlamamaktadır. Bu nedenle çalışmanın kısıtı, özel sermayeli 9 bankadan sürdürülebilirlik raporu yayımlayan sadece 5 tanesinin çalışmaya dahil edilmiş olmasıdır. Ileride yapılacak çalışmalarda bankaların sürdürülebilirlik performansını belirlemek amacıyla yeni göstergeler analize dahil edilerek farklı ÇKKV yöntemleri (AHP, TOPSIS, MOORA, WASPAS, TODIM vb.) kullanılabilir. Ayrıca değerlendirme sistemlerine insan düşünce yapısını daha iyi yansıtan bulanık mantık temelli yöntemlerden de bu amaçla yararlanılabilir. 


\section{Kaynaklar}

Akbank 2017 Sürdürülebilirlik Raporu, https://www.akbank.com/tr-tr/Yatirimci-iliskileri/Documents/2017_Akbank_S\%C3\%BCrd\%C3\%BCr\%C3\%BClebilirlik_Raporu.pdf (Erişim: 05.08.2018).

Akdoğan, Nalan; Gülhan, Ozan; Aktaş, Melike (2017) "The Relationship between corporate social responsibility reporting and corporate governance: evidence from Turkish banking sector". Journal of Modern Accounting and Auditing, Vol. 13, No. 5: 181-195.

Alp, Ihsan; Öztel, Ahmet; Köse, Mehmet Said (2015), “Entropi tabanlı MAUT yöntemi ile kurumsal sürdürülebilirlik performansı ölçümü: bir vaka çalışması”. Ekonomik ve Sosyal Araştırmalar Dergisi, C. 11, S.2: 65-81.

Aras, Güler; Tezcan, Nuray; Furtuna, Özlem Kutlu (2016), "Geleneksel bankacılık ve katılım bankacılı̆ında kurumsal sürdürülebilirlik performansının TOPSIS yöntemiyle karşılaştırılması". Yönetim: İstanbul Üniversitesi Işsletme Iktisadı Enstitüsü Dergisi, C. 27, S. 81: 58-81.

Aras, Güler; Tezcan, Nuray; Furtuna, Özlem Kutlu (2018), "Çok boyutlu kurumsal sürdürülebilirlik yaklaşımı ile Türk bankacılık sektörünün değerlemesi: Kamu-Özel Banka Farklılaşması”. Ege Akademik Bakış, C. 18, S.1: 47-62.

Aras, Güler; Tezcan, Nuray; Furtuna, Özlem Kutlu; Hacioglu Kazak, Evrim (2017), “Corporate sustainability measurement based on entropy weight and TOPSIS: A Turkish banking case study". Meditari Accountancy Research, Vol. 25, No.3: 391-413.

Atkins, Jill; Maroun, Warren (2015), "Integrated reporting in South Africa in 2012: Perspectives from South African institutional investors". Meditari Accountancy Research, Vol. 23, No.2: 197-221.

Bakır, Mahmut; Atalık, Özlem (2018), "Entropi ve Aras Yöntemleriyle Havayolu İşletmelerinde Hizmet Kalitesinin Değerlendirilmesi". İşletme Araştırmaları Dergisi, C. 10, S. 1: 617-638.

Ceran, Yunus (2009), "Türk Bankacılık Sektöründe İç Denetim”. Ömer Halisdemir Üniversitesi IiBF Dergisi, C. 2, S. 2: 168178.

Dadelo, Stanislav; Turskis, Zenonas; Zavadskas, Edmundas K.; Dadeliene, Ruta (2012), “Multiple criteria assessment of elite security personal on the basis of ARAS and expert methods". Economic Computation and Economic Cybernetics Studies and Research, Vol. 46, No. 4, 65-88.

Dyllick, Thomas; Hockerts, Kai (2002), "Beyond the business case for corporate sustainability. Business strategy and the environment", Vol. 11, No. 2: 130-141.

Eccles, Robert G.; Krzus, Michael P.; Rogers, Jean; Serafeim, George (2012). The need for sector-specific materiality and sustainability reporting standards. Journal of Applied Corporate Finance, Vol. 24, No. 2: 65-71.

Ecer, Fatih; Ulutagay, Gözde; Nasiboglu, Efendi (2011), “Does foreign ownership affect financial performance? An industrial approach". Middle Eastern Finance and Economics, Vol. 14: 152-166.

Ecer, Fatih (2015), "Performance evaluation of internet banking branches via a hybrid MCDM model under fuzzy environment". Economic Computation \& Economic Cybernetics Studies \& Research, Vol. 49, No. 2: 211-230.

Ecer, Fatih (2016), “ARAS yöntemi kullanılarak kurumsal kaynak planlaması yazılımı seçimi”. Alanya işletme Fakültesi Dergisi, Vol. 8, No. 1: 89-98.

Ecer, Fatih (2018), "An integrated Fuzzy AHP and ARAS model to evaluate mobile banking services". Technological and Economic Development of Economy, Vol. 24, No. 2: 670-695.

Elkington, J. (1997), Cannibals with Forks: The triple bottom line of 21st century business, Oxford: Capstone Publishing.

Goel, Puneeta (2010), "Triple Bottom Line Reporting: An analytical approach for corporate sustainability". Journal of Finance, Accounting \& Management, Vol. 1, No. 1: 27-42.

Goyal, Praveen; Rahman, Zillur; Kazmi, Alice A. (2013), "Corporate sustainability performance and firm performance research: Literature review and future research agenda". Management Decision, Vol. 51, No. 2: 361-379.

Goyal, Praveen; Rahman, Zillur; Kazmi, Alice A. (2015), "Identification and prioritization of corporate sustainability practices using analytical hierarchy process". Journal of Modelling in Management, Vol. 10, No. 1: 23-49.

Hu, Allan H.; Chen, Liang T.; Hsu, Chia W.; Ao, Jia G. (2011), “An evaluation framework for scoring corporate sustainability reports in Taiwan". Environmental Engineering Science, Vol. 28, No. 12: 843-858.

Hubbard, Graham (2009), "Measuring organizational performance: beyond the triple bottom line". Business Strategy and the Environment, Vol. 18, No. 3: 177-191.

Hussain, Nazim; Rigoni, Ugo; Orij, Rene P. (2018), “Corporate governance and sustainability performance: Analysis of triple bottom line performance". Journal of Business Ethics, Vol. 149, No. 2: 411-432. 


\section{Eskişehir Osmangazi Üniversitesi IïB Dergisi}

Kaderli, Yusuf; Gündüz, Çağdaş (2014), “Sürdürülebilirlik ve firma performansı: BisT 100 banka endeksi üzerine bir uygulama”. 18. Finans Sempozyumu Pamukkale Üniversitesi Bildiriler Kitabı: 607-625.

Karabasevic, Darjan; Zavadskas, Edmundas Kazimieras; Turskis, Zenonas; Stanujkic, Dragisa (2016), "The framework for the selection of personnel based on the SWARA and ARAS methods under uncertainties". Informatica, Vol. 27, No: 1: 49-65.

Khan, Habib U. Z.; Azizul Islam, Mohammad; Kayeser Fatima, J.; Ahmed, Khadem (2011), "Corporate sustainability reporting of major commercial banks in line with GRI: Bangladesh evidence". Social Responsibility Journal, Vol. 7, No. 3: 347-362.

Kılıç, Merve; Kuzey, Cemil (2018), "Assessing current company reports according to the IIRC integrated reporting framework". Meditari Accountancy Research, Vol. 26, No. 2: 305-333.

Korzeb, Zbigniew; Samaniego-Medina, Reyes (2019), "Sustainability Performance: A Comparative Analysis in the Polish Banking Sector". Sustainability, Vol. 11, No. 3: 653-668.

Kumar, Ranjan; Pande, Neerja; Afreen, Shamama (2018), “Developing a GRI-G4-based persuasive communication framework for sustainability reporting (SR) Examining top 10 Indian banks". International Journal of Emerging Markets, Vol. 13, No. 1: 136-161.

Li, Xianhxin; Wang, Kongsen; Liu, Liwen; Xin, Jing; Yang, Hongrui; Gao, Chengyao (2011), “Application of the entropy weight and TOPSIS method in safety evaluation of coal mines". Procedia Engineering, Vol. 26: 2085-2091.

Liao, Chin-Nung; Fu, Yan-Kai; Wu, Li-Chun (2016), "Integrated FAHP, ARAS-F and MSGP methods for green supplier evaluation and selection". Technological and Economic Development of Economy, Vol. 22, No: 5: 651-669.

Maubane, Pat; Prinsloo, Andre; Van Rooyen, Nadia (2014), "Sustainability reporting patterns of companies listed on the Johannesburg securities exchange". Public Relations Review, Vol. 40, No. 2: 153-160.

Nobanee, Haitham; Ellili, Nejla (2016), “Corporate sustainability disclosure in annual reports: Evidence from UAE banks: Islamic versus conventional". Renewable and Sustainable Energy Reviews, Vol. 55: 1336-1341.

Ömürbek, Nuri; Eren, Hande; Dağ, Okan (2017), “Entropi-Aras ve Entropi-Moosra yöntemleri ile yaşam kalitesi açısından AB ülkelerinin değerlendirilmesi”. Ömer Halisdemir Üniversitesi IiBF Dergisi, C. 10, S. 2: 29-48.

Ömürbek, Vesile; Aksoy, Esra; Akçakanat, Özen (2017), "Bankaların sürdürülebilirlik performanslarının ARAS, MOOSRA VE COPRAS yöntemleri ile değerlendirilmesi”. Süleyman Demirel Üniversitesi Vizyoner Dergisi, Vol. 8, No. 19: 1432.

Öner Kaya, Emine (2010), “Sürdürülebilir kalkınma sürecinde bankaların rolü ve Türkiye'de sürdürülebilir bankacılık uygulamaları". İ̧̧letme Araştırmaları Dergisi, C. 2, S. 3: 75-94.

Özçelik, Funda; Avcı Öztürk, Burcu (2014), "Evaluation of banks' sustainability performance in turkey with grey relational analysis". Muhasebe ve Finansman Dergisi, C. 63: 189-210.

Rebai, Sonia; Azaiez, Mohamed N.; Saidane, Dhafer (2016), “A multi-attribute utility model for generating a sustainability index in the banking sector". Journal of Cleaner Production, Vol. 113: 835-849.

Roca, Laurence C.; Searcy, Cory (2012), "An analysis of indicators disclosed in corporate sustainability reports", Journal of Cleaner Production, Vol. 20, No. 1: 103-118.

Saxena, Manisha; Kohli, Adam S. (2012), "Impact of corporate social responsibility on corporate sustainability: a study of the Indian banking industry". IUP Journal of Corporate Governance, Vol. 9, No. 4: 39-54.

Sobhani, Farid A.; Amran, Ahammad; Zainuddin, Yusuerri (2012), "Sustainability disclosure in annual reports and websites: a study of the banking industry in Bangladesh". Journal of Cleaner Production, Vol. 23, No. 1: 75-85.

Sun, Chia Chi (2014), "Combining grey relation analysis and entropy model for evaluating the operational performance: an empirical study". Quality \& Quantity, Vol. 48, No. 3: 1589-1600.

Şekerbank $2015 \quad$ Sürdürülebilirlik Raporu, https://www.sekerbank.com.tr/docs/default-source/hakk\%C4\%B1m\%C4\%B1zda_doc/surdurulebilirlikraporu2015.pdf?sfvrsn=2 (Erişim: 05.08.2018).

TEB 2014-2015 Sürdürülebilirlik Raporu, https://www.teb.com.tr/UPLOAD/PDF/CSR-report/TEB-SR-2014-15-TR.pdf (Erişim: 05.08.2018).

Türkiye İş Bankası 2017 Sürdürülebilirlik Raporu, https://www.isbank.com.tr/TR/hakkimizda/surdurulebilirlik/raporlarimiz/Documents/SurdurulebilirlikRaporu2017.pdf (Erişim: 05.08.2018).

Ulutagay, Gözde; Ecer, Fatih; Nasibov, Efendi (2015), "Performance evaluation of industrial enterprises via fuzzy inference system approach: a case study". Soft Computing, Vol. 19, No. 2: 449-458. 
Ağustos 2019, C. 14, S. 2

Weber, Olaf (2016), "The sustainability performance of Chinese Banks: institutional impact", SSRN Network Papers.

Weber, Olaf (2017), "Corporate sustainability and financial performance of Chinese banks". Sustainability Accounting, Management and Policy Journal, Vol. 8, No. 3: 358-385.

Wei, Guiwu (2016), "Picture fuzzy cross-entropy for multiple attribute decision making problems". Journal of Business Economics and Management, Vol. 17, No. 4: 491-502.

Yapı Kredi Bankası 2017 Sürdürülebilirlik Raporu, https://assets.yapikredi.com.tr/WebSite/_assets/pdf/arsiv/surdurulebilirlik/SurdurulebilirlikRaporu2017.pdf?v2 (Erişim: 05.08.2018).

Zahid, Muhammad; Ghazali, Zulkipli (2015), “Corporate sustainability practices among Malaysian REITs and property listed companies". World Journal of Science, Technology and Sustainable Development, Vol. 12, No. 2: 100-118. 


\section{EK- Özel sermayeli bankalara ilişkin bilgiler}

Türkiye İş Bankası, 2017 itibarıyla 362,4 milyar TL seviyesindeki aktif büyüklüğü ile Türkiye'nin en büyük özel bankasıdır. İş Bankası, 24868 çalışanla birlikte yaklaşık 15 milyon müşteriye hizmet vermektedir. İş Bankası özel bankalar arasında, toplamda 1342 yurt içi şube ile en büyük şube ağına, 6545 Bankamatik ile de en geniş ATM ağına sahiptir. Banka aynı zamanda KKTC'de 15, İngiltere, Irak ve Kosova'da ikişer, Bahreyn'de ise bir adet olmak üzere toplam 22 yurt dışı şubede hizmet sunmaktadır (Türkiye İş Bankası Sürdürülebilirlik Raporu, 2017).

Akbank 2017 yılsonu itibarıyla yurt içinde 800 şubesi, yaklaşık 14 bin çalışandan oluşan insan kaynağı ve 4400 civarında ATM'si ile Türkiye çapında güçlü bir hizmet altyapısına sahiptir. Banka yaklaşık 15 milyon bireysel, 1,1 milyonu aşkın ticari ve KOBi ile 6500'e yaklaşan kurumsal müşterisiyle yaygın bir müşteri tabanına sahiptir (Akbank Sürdürülebilirlik Raporu, 2017).

1953 yılında kurulan Şekerbank 273 şube, 280 ATM, 9 bölge müdürlüğü (2 İstanbul, 7 Anadolu) ve 1 yurt dışı temsilciliği ile hizmet vermektedir. Ayrıca banka 3500 civarında çalışana, 27000'e yakın kadın esnaf ve işletme müşterisine, 240 bin çiftçi müşterisine ve 550 bin KOBi müşterisine sahiptir (Şekerbank Sürdürülebilirlik Raporu, 2015).

1927 'de İzmit'te Kocaeli Halk Bankası T.A.Ş. unvanıyla faaliyetlerine başlayan Türk Ekonomi Bankası A.Ş. (TEB) 5 milyona ulaşan müşterisine 10 bine yakın çalışanı, 532 şubesi ve 1700 ATM'si ile hizmet vermektedir. TEB müşterilerine, kurumsal, KOBi, hazine ve sermaye piyasaları, bireysel ve özel bankacılık hizmetlerinin yanı sıra iştirakleri ve grup şirketleri aracılığıyla da, yatırım, leasing, faktöring, sigorta ve portföy yönetimi alanlarında geniş bir yelpazeye dağılmış finansal hizmet ve ürünler sunmaktadır (TEB Sürdürülebilirlik Raporu, 2015).

1944 yılında, Türkiye'nin perakende bankacılık odaklı ilk ulusal özel bankası olarak kurulan Yapı Kredi Bankası, 320 milyar TL toplam aktif büyüklüğü ile Türkiye'nin en büyük dördüncü özel bankasıdır. Bankanın 866 şubesi, 18500 çalışanı, 4300 ATM'si ve 13,3 milyon müşterisi bulunmaktadır (Yapı Kredi Bankası Sürdürülebilirlik Raporu, 2017). 